\title{
A review of starch digestion in the lactating dairy cow and proposals for a mechanistic model: 1 . Dietary starch characterisation and ruminal starch digestion
}

\author{
J.A.N. Mills ${ }^{1}$, J. France ${ }^{1}$ and J. Dijkstra ${ }^{2}$ \\ 'The University of Reading. Centre for Dairy' Research, Department of Agriculture \\ Earley Gute, PO Box 236, Reading RG6 6AT, UK \\ - WIAS Animal Nutrition, Wageningen Agricultural University \\ Marikeweg 40, PO Box 338, 6700 AH Wageningen. The Netherlands
}

(Received 16 July 1999; accepted 20 July 1999)

\begin{abstract}
The objective of this paper is to review the literature concerning starch digestion in the rumen of the lactating dairy cow and to propose the framework for a mechanistic model representing this process that may be used as part of a larger model of whole rumen function. The review defines starch as it occurs in the diet of the dairy cow, followed by a detailed description of the digestion of starch in the rumen. Emphasis is placed on the role of the microbial population in the degradation of starch and the significance of both amylolytic bacteria and protozoa. During the investigation, use is made of data gathered from both in vivo, in vitro and in situ studies concerning mainly lactating dairy cows. Regression relationships are presented to describe the significance of dietary starch intake, starch source and processing method on digestion characteristics. The quantity of rumen escape starch is increased at high starch intakes. Maize and sorghum starches tend to be more slowly degraded within the rumen than other cereals and they also benefit to a greater extent from physical and chemical processing techniques designed to increase numinal and total tract starch digestion. Other factors influencing the nature of starch digestion are also presented in order to allow the interpretation of experimental data and hence the development of a conceptual model of starch digestion. The review subsequently examines starch digestion in the rumen as it is represented in extant models of ruminant digestion. The essential elements of a rumen model that would accurately account for the fate of dictary starch within the rumen are identified. Finally, a scheme representing starch digestion in the dairy cow that may be incorporated into a model of whole rumen function is presented.
\end{abstract}

KEY WORDS: starch, digestion, model, dairy cow, rumen 


\section{INTRODUCTION}

\section{Current methods of feed evaluation}

In the UK current methods for the energetic assessment of feedstuffs in the diet of the dairy cow are based around the Metabolisable Energy (ME) system (Agricultural Research Council, ARC, 1980). This empirical method of assessing the energy requirements of the lactating cow where milk output is known, fails to adequately represent situations where the rations fed are not typical of those used to develop relationships within the ME system itself. Whilst this approach concerns itsclf with the total amount of encrgy required by the cow, it fails to account for the energy source within the diet. There is substantial evidence demonstrating that the form of carbohydrate in the diet can influence lactational performance, both in terms of milk volume and the yicld of milk constituents (Sutton, 1985; MacRae et al., 1988; De Visser, 1993). More specifically, the nature of the dietary starch source can affect milk production through differences in susceptibility to ruminal degradation and total tract digestion (Nocek and Tamminga, 1991). Variation in starch source can significantly affect the energy and protein interaction within the rumen and yields of individual volatile fatty acids (VFA's) resulting from microbial fermentation of the feedstuffs. High levels of ruminal starch availability may depress fibre degradation where amylolytic microbes predominate at the expense of fibrolytic microbes. It is this variation in nutrient supply to the cow from isoenergetic diets that impacts on milk yield and composition (MacRac et al., 1988; Thomas and Martin, 1988). Therefore current methods of feed cvaluation are too imprecise to deal successfully with a nutrient such as starch.

Feeding today's dairy cow

As a result of genetic progress within the national dairy herd, many cows are capable of peak milk yields in excess of $50 \mathrm{~kg} \mathrm{day}^{-1}$. This level of output demands that the ration provides sufficient energy to minimise the negative energy balance experienced by the cow at this stage of lactation. In practice, due to feed intake constraints, the energy density of the diet is increased as a means to raise the total amount of encrgy consumed. Starchy fcedstuffs, most notably the cereal grains, provide a practical and cost effective method of delivering a sufficiently energy dense diet. Indecd, even the forage'component of the ration may contain significant quantities of starch. This is particularly apparent where forage maize and whole-crop wheat silages feature as dict ingredients.

The feeding of such energy dense starch rich diets, to lactating cows has highlighted the need for a thorough understanding of starch digestion throughout the gastro-intestinal tract. Recently much emphasis has been placed on the synchroni- 
sation of energy and protein supply within the rumen in order to maximise production efficiency, eliminate digestive disorders and even reduce environmental pollution. Key to this whole concept is the fraction of the diet referred to as fermentable carbohydrate, of which starch is an important component. Estimates of the rate and extent of ruminal starch fermentation, and subsequent intestinal digestion of rumen undegraded starch are currently required to ration dairy cows and effectively employ the concept of the energy and protein interaction.

\section{Future methods of feed evaluation}

Many researchers (MacRac et al., 1988; Beever et al., 1991; AFRC, 1999) encourage a move away from the traditional approach of calculating a cow's energetic requirements and towards the prediction of responses to nutrients. Prediction of both milk yicld and the yicld of fat, protcin and lactose for different dietary inputs would allow development of a least cost fecding strategy and therefore produce major cconomic benefits for the dairy farmer. This approach is highly relevant with respect to predicting nutrient supply and production responses as a consequence of feeding various starch sources in different situations. It is generally accepted that such predictions of animal response will come as the direct result of the mathematical modetling of dairy cow digestion and metabolism (AFRC, 1999). Becver et al. (1991) reviewed both empirical and mechanistic approaches to modelling lactational performance by the dairy cow. Mechanistic models of the digestion processes, involving various levels of organisation within the animal, offer the potential to reliably predict the products of digestion even when the feedstuffs under scrutiny differ from those used to derive the equations forming the model (Beever et al., 1991; Baldwin, 1995).

A mechanistic model of starch digestion in the gastro-intestinal tract of ruminants can be constructed by first examining the structure of the digestion process and dividing it into critical components. Analysis of the bchaviour of the system in terms of these individual components and their interrelations with one another provides the mathematical basis on which the model is built (Forbes and France, 1993). France and Thornley (1984) detail the construction of a mechanistic model using the concept of organisational hicrarchy. This reductionist method of modelling starch digestion involves a description of the process at level $i$ in terms of the components at level $i-1$ or lower. This allows biologically meaningful relationships to form the basis of the model. It is for this reason that a working model can pinpoint areas where the biological understanding or representation of the system is inadequate (France et al., 1998). Therefore a dynamic model is a powerful research tool. A dynamic mechanistic mathematical model of starch digestion and glucose absorption has the potential to create a system for quantifying the impact of altering starch type or quantity in the diet with regard to the effects on the end 
products of digestion and exogenous glucose supply. Van Soest (1994) catagorises the modelling process into the four stages of understanding, mathematical expression, validation and application. This review is aimed at understanding the process as described in the literature.

\section{Objectives}

The first objective of this paper is to revicw the literature relating to the digestion of starch in the rumen of the dairy cow. This will allow characterisation and quantification of the factors affecting the rate and extent of starch degradation in the rumen. The second objective is to identify a suitable framework for a dynamic mechanistic model of ruminal starch digestion that can be used to improve existing models of whole rumen function.

Starch digestion data from lactating dairy cows

Research into starch digestion by ruminants has been reviewed periodically with general reviews (Waldo, 1973; Ørskov, 1986; Rooney and Pflugfelder, 1986; Huntington, 1997), revicws on the effects of cereal grain processing on starch digestion (Hale, 1973; Ørskov, 1976; Theurer, 1986) and a review of small intestinal starch digestion (Owens et al., 1986). However, these reviews have focussed on research concerned primarily with sheep and non-lactating cattle. Over the last ten years an increasing amount of data has been published regarding the digestion of starch in lactating dairy cattle, some of which has been summarised by Nocek and Tamminga (1991) and Reynolds et al. (1997). In order to achieve the objectives of this study, starch digestion data from 22 in vivo experiments involving lactating dairy cattle have been summarised in the appendix and certain elements of these data are presented throughout. In situ and in vitro data concerning the degradation of dietary starch within the rumen have also been presented throughout.

\section{STARCH IN THE DIET OF THE LACTATING DAIRY COW}

\section{Starch chemistry}

Starch is present in plants as a reserve carbohydrate, particularly in seeds, fruits, tubers and roots. Starches differ in chemistry depending on source and are a mixture of two polysaccharides, amylose and amylopectin. Although glucose is the basic component of both of these polysaccharides, amylose demonstrates a linear structure ( $\alpha 1,4$ linkages) whilst amylopectin shows a branched structure $(\alpha 1,4$ 
and $\alpha 1,6$ linkages). Starch is stored in varying locations and in a variety of granular forms; spheres, ellipsoids, polygons, platelets, and irregular tubules. Figure 1 shows the molecular structure of amylopectin.

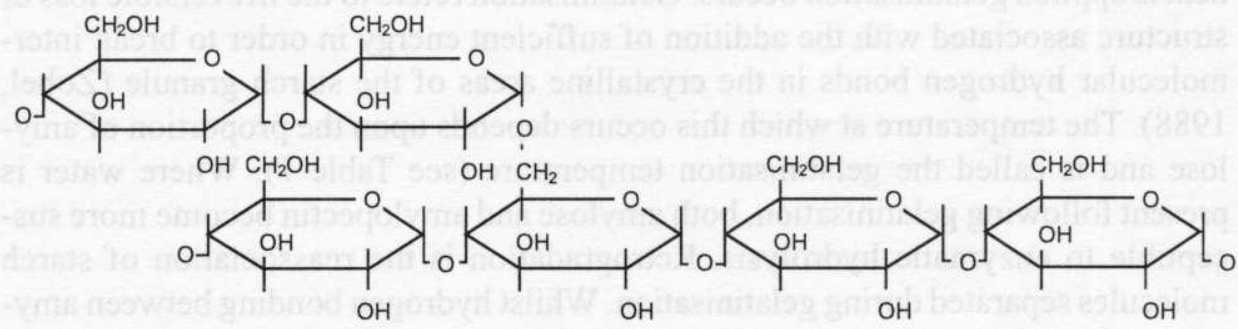

Figure 1. The molecular structure of amylopectin

Starches exist in highly organised granules in which amylopectin and amylose are held together by hydrogen bonding. Granules display dimensions ranging from 0.5 to $175 \mathrm{~mm}$ (Zobel, 1988) but most are within the ranges shown in Table 1 . The granular form of the starch tends to be species specific to such an extent that the source can be determined from a scanning electron micrograph. Typical granular forms are shown in Figure 2.

Starch granules possess both crystalline and amorphous areas (Rooney and Pflugfelder, 1986). The crystalline region is composed of amylopectin and it is resistant to water entry and enzyme attack. The amorphous region consists of higher
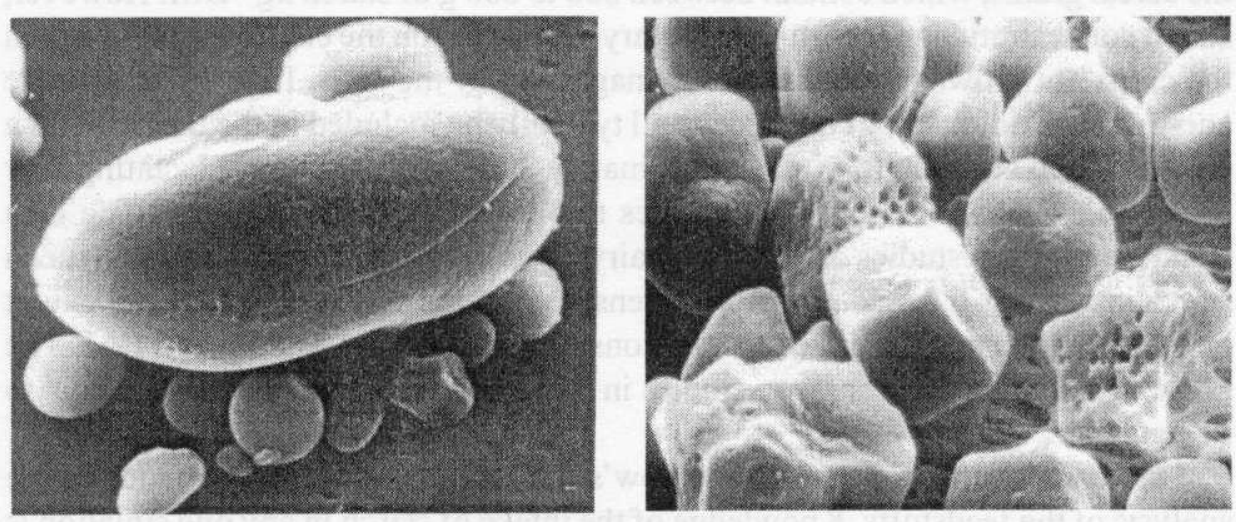

Figure 2. Scanning elektron micrographs of wheat starch (left) and maize starch; Kent and Evers, 1994 
concentrations of amylose and it is of a lower density than the crystalline area. Enzyme degradation begins in the amorphous region and water can also pass through this area (Rooney and Pflugfelder, 1986). Swelling of starch granules is a reversible process as they take up water along with gradual heating. However as more heat is applied gelatinisation occurs. Gelatinisation refers to the irreversible loss of structure associated with the addition of sufficient energy in order to break intermolecular hydrogen bonds in the crystalline areas of the starch granule (Zobel, 1988). The temperature at which this occurs depends upon the proportion of amylose and is called the gelatinisation temperature (see Table 1). Where water is present following gelatinisation, both amylose and amylopectin become more susceptible to enzymatic hydrolysis. Retrogradation is the reassociation of starch molecules separated during gelatinisation. Whilst hydrogen bonding between amylose and amylopectin redevclops, the initial character of the starch granule does not return. Retrogradation can produce forms of starch that are resistant to enzyme attack.

The amylose content of most cereal starches is between 20 and $35 \%$, but plant breeding programs have led to the production of cultivars with abnormally high or low amylose contents (Kent and Evers, 1994). Due to the appearance of the endosperm, high amylopectin cultivars are described as waxy varieties. Waxy maize cultivars contain up to $99 \%$ amylopectin. The proportion of amylose in maize will rise as the growing crop matures. Table 1 displays values for amylose content in several common starch sources that could be included in the diet of a dairy cow.

\section{Starch concentration in the diet and starch analysis}

The majority of starch in the dict of the high yielding dairy cow originates from the cereal grains, which contain between 600 to $800 \mathrm{~g}$ of starch $\mathrm{kg}^{-1} \mathrm{DM}$. However, starch concentration in feedstuffs will vary depending on the environment in which the crops are grown, genotype and management of the crop. In order to achieve energy dense rations, starch sources will typically be included in the diet to yield a dietary starch concentration of approximately $200 \mathrm{~g} \mathrm{~kg}^{-1} \mathrm{DM}$. For a lactating cow consuming $25 \mathrm{~kg} D M_{\text {day }}{ }^{-1}$ this equates to $5 \mathrm{~kg}$ day ${ }^{-1}$ of starch intake. The data summarised from studics on lactating dairy cows in the appendix shows that mean starch intake was $6.2 \mathrm{~kg} \mathrm{day}^{-1}$. More extensive systems may rely to a greater extent on forage in the ration with concentrations of starch as low as $20 \mathrm{~g} \mathrm{~kg}^{-1} \mathrm{DM}$. The range in starch intakes for those studies in the appendix was from $0.07 \mathrm{~kg} \mathrm{day}^{-1}$ to $11 \mathrm{~kg} \mathrm{day}^{-1}$.

One complication in assessing a cow's dietary intake of starch relates to the analysis of the feedstuffs. Knowledge of the intake of starch in any one situation is crucial to interpreting the effects on digestion. However, Beever et al. (1996) demonstrated the shortcomings of current analytical procedures for the measurement 
Physical and chemical characteristics of starch granules for a range of feedstuffs

TABLE 1

\begin{tabular}{|c|c|c|c|c|c|}
\hline Starch source & $\begin{array}{c}\text { Granule size, } \mu \mathrm{m} \\
\text { range }\end{array}$ & $\begin{array}{c}\text { Granule size, } \mathrm{mm} \\
\text { mean }\end{array}$ & Amylose, $\%$ & $\begin{array}{c}\text { Gelatinisation range, } \\
{ }^{\circ} \mathrm{C}\end{array}$ & $\begin{array}{l}\text { General description of } \\
\text { granules }\end{array}$ \\
\hline Barley & $2-35$ & 20 & 22 & $59-64$ & Round, eliptical \\
\hline Maize - waxy & $5-25$ & 15 & 1 & $63-72$ & Round, oval indentations \\
\hline Maize - high amylose & $5-25$ & 15 & 80 & $85-87$ & Round \\
\hline Potato & $15-100$ & 33 & 24 & $56-69$ & Egg like, oyster indentations \\
\hline \multirow[t]{4}{*}{ Wheat } & Large & Large $25^{*}$ & & & Round, eliptical \\
\hline & $15-30 *$ & & 25 & $62-75$ & \\
\hline & Small & Small & & & \\
\hline & $1-10^{*}$ & $5 *$ & & & \\
\hline Oats & $2-60 *$ & 25 & 27 & & Round \\
\hline
\end{tabular}

source: Pomeranz, 1984

* Kent and Evers, 1994 
of starch content of maize silage. Analyses of the same low dry matter (LDM) and high dry matter (HDM) maize silages between 8 different laboratories displayed widely different results as shown in Table 2. Beever et al. (1996) described inter laboratory variation in starch analysis as unacceptable.

TABLE 2

The starch content for two maize silages as analysed by 8 different laboratories

\begin{tabular}{lcc}
\hline Starch, $\mathrm{g} \mathrm{kg}^{-1} \mathrm{DM}$ & Low dry matter maize silage & High dry matter maize silage \\
\hline Mean \pm SEM & $228 \pm 35.6$ & $26 ! \pm 42.4$ \\
Range & $165-272$ & $194-311$ \\
\hline
\end{tabular}

Beever et al., 1996

Although there is an official AOAC method for determining the starch content of ccreals (AOAC, 1995), many studies involve at least some variation on any one method of analysis. MacRae and Armstrong (1968) reviewed the methods employed for starch estimation whilst proposing their own technique. Both MacRae and Armstrong (1968) and AOAC (1995) rely on the use of glucoamylase to degrade starch completely to glucose. The nature of the enzyme is such that it attacks $\alpha 1: 4, \alpha 1: 6$ and $\alpha$ 1:3 linkages. The starch must be gelatinised prior to enzyme action. Reynolds et al. (1997) suggest that inter laboratory variation as seen by Beever et al. (1996) can be attributed to differences in sample preparation, the source of enzyme used and the conditions used for enzymatic hydrolysis. New analytical techniques allowing increased precision are being developed (Cone et al., 1992; Brunt et al., 1998) but they are not currently available for routine use. Therefore the results of Beever et al. (1996) highlight the need for caution during comparison of data on starch digestion from different sources.

\section{STARCH DIGESTION IN THE RETICULORUMEN}

The first site of starch digestion is the reticulorumen, where the starch is fermented by the resident microflora. The rate and extent of this fermentation will depend on starch type, processing prior to ingestion, other feedstuffs in the dict and feeding management of the cow. Such factors are discussed later. Starch is hydrolysed first by the extracellular microbial enzymes $\alpha$ and $\beta$-amylase. The random action of $\alpha$-amylase allows it to degrade both amylose and the linear regions of amylopectin. $\beta$-amylase cleaves starch chains at their end points and it degrades both amylose and the peripheral regions of amylopectin. Maltases, maltose phosphorylases, or 1,6-glucosidases, subsequently hydrolyse maltose 
and isomaltose to produce glucose or glucose-1-phosphate. Kotarski et al. (1992) identified 15 strains of amylolytic bacteria. Individually these bacteria produced one or more of 8 amylolytic enzymes. However, due to certain enzymes being specific to only a few species of bacteria, greatest degradation of feed starch requires integration of bacterial species (Cotta, 1992). The survival of these amylolytic bacteria within the rumen is dependent on their rapid growth rates and high substrate affinities.

Protozoa also influence the ruminal degradation of starch through fermentation, and in some circumstances they may equal the rumen bacteria in total mass, although due to a much larger size, be present in smaller numbers. Eadie and Mann (1970) and Slyter et al. (1970) describe how high concentrate diets decreased rumen protozoa numbers considerably, due to the increasingly acidic conditions observed as levels of fermentable carbohydrate increased. Protozoa have been shown to slow ruminal starch fermentation (Mackic and Gilchrist, 1978; Mendoza et al., 1993). In the defaunation study of Mendoza et al. (1993) the presence of protozoa reduced ruminal starch digestion in sheep by $9 \%$. Unfortunately, the actual proportions of protozoa as percentages of the ruminal microorganisms in the control sheep were not measured. However, Veira and Ivan $(1983)$ showed a significant decline $(\mathrm{P}<0.05)$ in the amount of ruminal starch digestion for defaunated shecp fed diets based on maize silage and maize grain. Veira and Ivan (1983) also observed significant increases in rumen ammonia concentration where protozoa were present in large numbers. Such an elevation in ammonia, on a dict that was low in crude protein $(11.3 \%)$, could have increased microbial activity producing the observed increase in starch digestion. Defaunation produced increases in rumen propionate and reductions in rumen acetate and butyrate concentrations, either as a direct result of the increased fermentation of starch or decreased fermentation of fibre within the rumen (Mendoza et al., 1993). Whitelaw et al. (1984) showed that methane production was elevated, probably as a result of increased hydrogen availability, where protozoa were present in the rumen of cattle.

The reason for this reduction in the rate of starch digestion is that protozoa can engulf starch particles and directly affect the availability of dietary starch for fermentation by other microbes. This process can lead to a stabilisation of rumen $\mathrm{pH}$ (Veira and Ivan, 1983). Whilst all entodiniomorphid species engulf starch grains, certain holotrich species of protozoa are more selective (Williams and Coleman, 1997). The rate of starch uptake by protozoa is both species and $\mathrm{pH}$ dependent (Coleman, 1992). This engulfing process creates a time lag for the fermentation of the starch, especially on starch rich diets, and lowers the risk of acidosis (Van Soest, 1994). However, if these protozoa ingest too much starch lysis can result. This may explain why high starch diets can also lead to the depletion of protozoa from the rumen in individual cows. Protozoa also ingest 
other rumen microbes and this may result in the reduction of bacterial $\alpha$-amylase activity as seen by Mendoza et al. (1993). The rate of uptake of bacteria by protozoa is $\mathrm{pH}$ dependent and displays an optimum at $\mathrm{pH} 6.0$ declining to zero at $\mathrm{pH} 5.0$ and $75 \%$ at $\mathrm{pH} 7.0$ (Williams and Coleman, 1997). The presence of protozoa may also lower the risk of ruminal acidosis due to their uptake of lactic acid, which seems to be more effective than the same process occurring in bacteria (Williams and Coleman, 1997).

The glucose produced from the hydrolysis of starch in the rumen is rarely detectable due to its rapid uptake and metabolism by the ruminal microorganisms. Pyruvate is subsequently produced as a result of glycolysis. Several chemical pathways are then available for the conversion of pyruvate to the volatile fatty acids (VFA) which can be absorbed by the cow from the rumen. It is the phosphorylation of ADP to ATP during the production of the VFAs which creates an energy supply for the microbes and allows microbial growth, provided an adequate supply of amino acids, ammonia and other minerals are present. Methane, carbon dioxide and hydrogen are produced in addition to the VFA from the fermentation of starch. Typical composition of gas in the rumen is $30-40 \%$ methane, $40 \% \mathrm{CO}_{2}$ and $5 \%$ hydrogen, along with varying amounts of nitrogen and oxygen from ingested air (Mcdonald et al., 1995). Methanogenesis involves the reduction of $\mathrm{CO}_{2}$ by $\mathrm{H}_{2}$, whilst $\mathrm{CO}_{2}$ is formed mainly from fermentation but also from the reaction between bicarbonate and organic acids. A minor pathway also exists for the production of acctate from $\mathrm{CO}_{2}$ and $\mathrm{H}_{2}$ involving acetogenic bacteria (Genthner et al., 1981).

Figure 3 clearly shows the principal pathways involved in the production of VFA, $\mathrm{CO}_{2}$, methane and $\mathrm{H}_{2}$ from feed carbohydrate. The fermentation of high levels of starch, as seen with high concentrate diets, leads to a high proportion of the glucogenic VFA, propionate. This propionate production is principaliy via the lactate - acrylate pathway with Megasphaera elsdinii being the microbe responsible (Van Soest, 1994). High forage dicts with low or moderate levels of starch are fermented to produce greater concentrations of the lipogenic VFA's acetate and butyrate, while propionate production switches to the pathway through oxaloacetatc and succinate.

Therefore the rate and extent of starch digestion can affect the composition of VFA produced, ruminal $\mathrm{pH}$ and the quantity of undegraded feed starch leaving the rumen. Indeed ruminal digestion of starch is the direct result of the competition between passage from the rumen and degradation. This concept is described in more detail later. Data from the appendix highlight the wide variation in digestibility coefficients for different starch sources in a range of dietary situations. The mean digestibility of starch in the rumen for the 15 studies with such measurements was $59 \%$. The spread of results was from 27 to $92 \%$. The reasons for such variation will be discussed in the latter half of this review. 


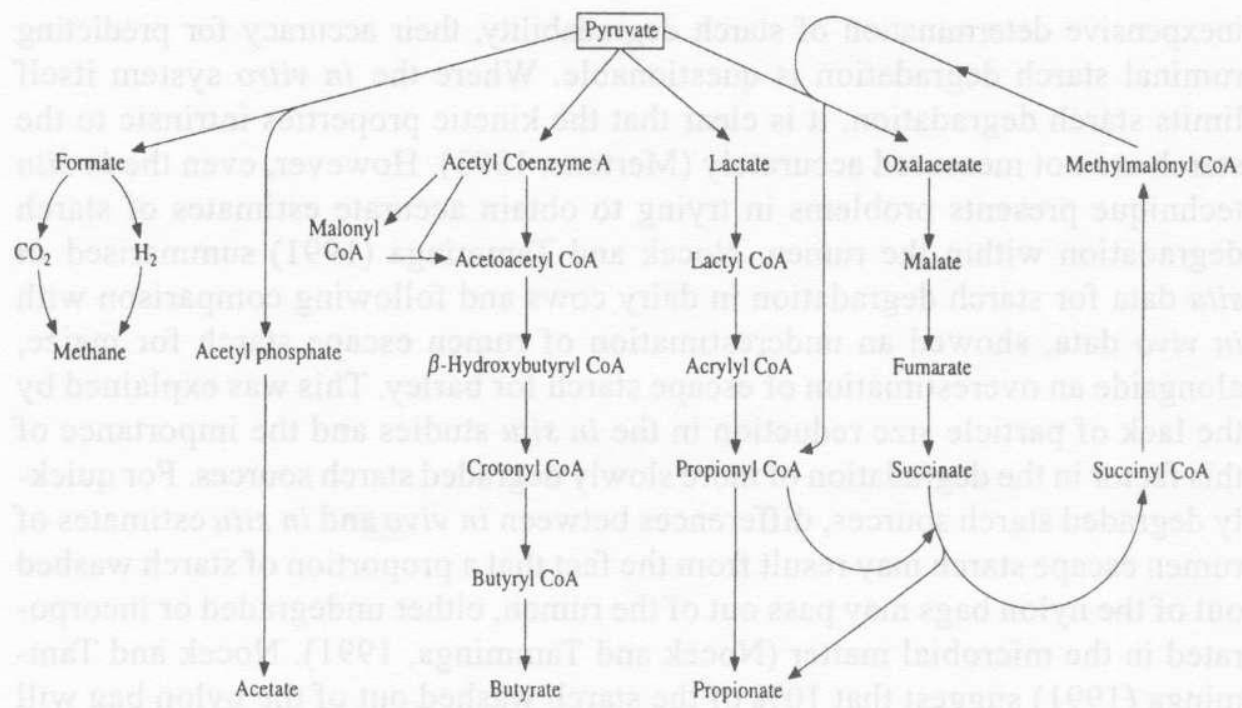

Figure 3. Conversion of pyruvate to volatile fatty acids in the rumen; Mcdonald et al., 1995

In vitro and in situ determinations of the rate of starch degradation in the rumen

Whilst the degree of dietary starch degradation that occurs in the rumen is a major influence on digestion as a whole, it is the rate of this degradation that may be more important in terms of feeding the dairy cow (Beever, 1999). From a modelling perspective Mertens (1993) emphasises the importance of avoiding the use of static coefficient, such as digestibility, in the description of a dynamic system such as starch digestion. Therefore reliable techniques are required that can quantify the rate as well as the extent of degradation for different starch sources within the rumen. Cone (1991) described the determination of starch degradability using an in vitro technique involving the incubation of starch with rumen fluid, $\alpha$-amylase, pancreatin, or a freeze-dried cell free preparation of rumen fluid. Neither $\alpha$-amylase nor pancreatin provided degradation results consistent with those of rumen fluid. However in this respect the use of the freeze-dried, cell free, preparation of rumen fluid was successful. De Visser (1993) summarised investigations by Tamminga et al. (1989) in which comparisons of both in vitro and in situ methods for the determination of the extent of rumen starch degradation were made. The extent of degradation varied considerably between the two methods and for different feedstuffs. Therefore, whilst in vitro methods of analysis offer a quick and 
inexpensive determination of starch degradability, their accuracy for predicting ruminal starch degradation is questionable. Where the in vitro system itself limits starch degradation, it is clear that the kinetic properties intrinsic to the starch are not measured accurately (Mertens, 1993). However, even the in situ technique presents problems in trying to obtain accurate estimates of starch degradation within the rumen. Nocck and Tamminga (1991) summarised in situ data for starch degradation in dairy cows and following comparison with in vivo data, showed an underestimation of rumen escape starch for maize, alongside an overestimation of escape starch for barley. This was explained by the lack of particle size reduction in the in situ studies and the importance of this factor in the degradation of more slowly degraded starch sources. For quickly degraded starch sources, differences between in vivo and in situ estimates of rumen escape starch may result from the fact that a proportion of starch washed out of the nylon bags may pass out of the rumen, either undegraded or incorporated in the microbial matter (Nocek and Tamminga, 1991). Nocek and Tamminga (1991) suggest that $10 \%$ of the starch washed out of the nylon bag will escape rumen degradation. Using this correction factor of $10 \%$ for the in situ data, Nocek and Tamminga (1991) were able to show similar rumen degradabilitics to those obtained in vivo for a variety of starchy feedstuffs. Ewing and Johnson (1987) concluded that both in vitro and in vivo techniques ,vastly underestimated" ruminal starch digestion rates following the development of a model of maize starch digestion in beef steers.

The in situ data presented by Nocek and Tamminga (1991) shows multiple measurements for individual feeds, although processing method is not recordcd. Table 3 uses mean values to summarise these data. For most investigations into the in situ disappcarance of starch, the proportion of starch undegraded following $48 \mathrm{~h}$ of incubation is negligible. Indeed the highest reported value is only $3 \%$ and this was for crossbred steers fed dry ground sorghum (HerreraSaldana et al., 1990b). This suggests that almost all starch is potentially degradable in the rumen. However, the effective degradability will depend on the relative rates of starch passage from the rumen and the rate of starch degradation within the rumen. This concept of all dietary starch being potentially degradable is important from a modelling perspective and will be discussed later. Figure 4 shows the disappearance of various maize starches from the rumen in non-lactating Jersey cows (Philippeau and Michalet-Dorcau, 1998). Whilst the factors influencing this degradation will be discussed later, the rate of starch disappearance tends to decline as incubation time increases. For 3 of the 5 starch sources in Table 3 the soluble fraction equates to greater than $50 \%$ of the total, and this highlights the significance of this fraction as a component of both ruminal and total tract digestion. 


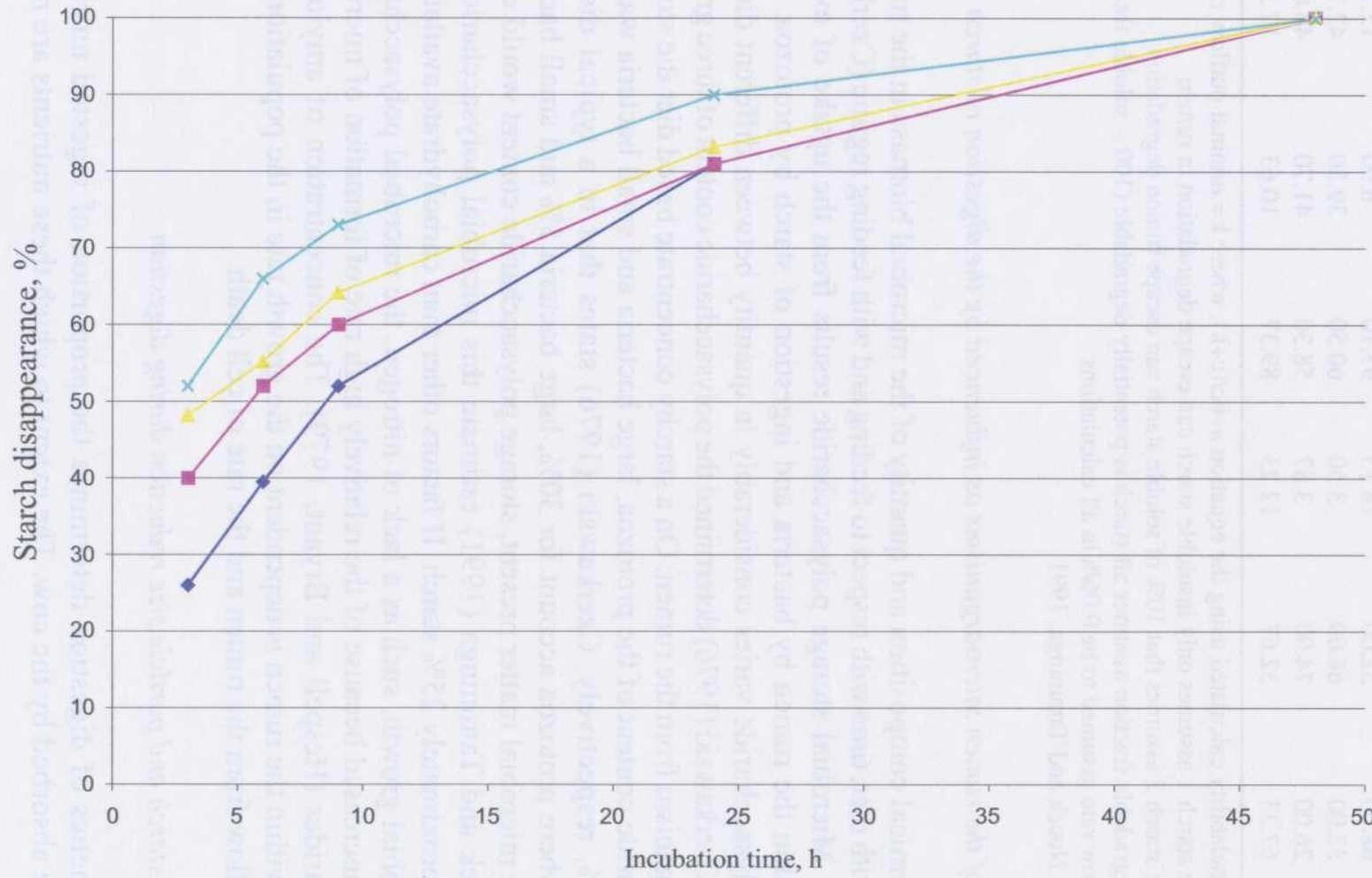

Figure 4. In situ chopped maize starch disappearance from the rumen in non-lactating dairy cattle; Philippeau and Michalet-Doreau, 1998 
TABLE 3

In situ mean degradability characteristics for different starch sources in lactating dairy cows

\begin{tabular}{lcccccc}
\hline $\begin{array}{l}\text { Starch } \\
\text { source }\end{array}$ & $\begin{array}{c}\text { Soluble } \\
\text { fraction (a) } \\
\%\end{array}$ & $\begin{array}{c}\text { Slowly } \\
\text { degradable } \\
\text { fraction (b) \%** }\end{array}$ & $\begin{array}{c}\mathrm{kd}(\mathrm{c}) \\
\% / \mathrm{h}\end{array}$ & $\begin{array}{c}\text { Effective } \\
\text { degradability } \\
\% *\end{array}$ & $\begin{array}{c}\text { Rumen } \\
\text { escape } \\
\text { starch 1\% }\end{array}$ & $\begin{array}{c}\text { Rumen } \\
\text { escape } \\
\text { starch 2 \% }\end{array}$ \\
\hline Barley & 54.50 & 45.50 & 19.80 & 90.25 & 9.75 & 15.20 \\
Wheat & 68.00 & 32.00 & 18.15 & 93.10 & 6.90 & 13.70 \\
Sorghum & 32.00 & 68.00 & 3.50 & 60.50 & 39.50 & 42.70 \\
Maize & 26.00 & 74.00 & 3.87 & 58.30 & 41.70 & 44.00 \\
Tapioca & 67.33 & 32.67 & 12.23 & 89.37 & 10.63 & 17.37 \\
\hline
\end{tabular}

effective degradability calculated using the equation $a+b c /(c+k)$, where $k=$ ruminal outflow rate rumen escape starch 1 assumes only insoluble starch can escape degradation in rumen rumen escape starch 2 assumes that $10 \%$ of soluble starch can escape rumen degradation

** slowly degradable fraction assumes all starch is potentially degradable ( 100 - soluble fraction) ruminal outflow rate assumed to be $0.06 / \mathrm{h}$ in all calculations

adapted from Nocek and Tamminga, 1991

\section{Dynamics of the rumen microorganisms as influenced by the digestion of starch}

The chemical composition and quantity of the microbial biomass in the rumen will vary with diet, time with respect to feeding and with feeding regime (Czerkawski, 1976). Microbial storage polysaccharide results from the uptake of excess hexose within the rumen by bacteria and ingestion of starch by protozoa. This storage polysaccharide varies considerably in quantity between different dietary situations. Czerkawski (1976) determined the polysaccharide content of three groups of microorganism from the rumen. On a starchy concentrate based diet the storage polysaccharide content of the protozoa, large bacteria and small bacteria was 34 , 20 and $8 \%$, respectively. Czerkawski $(1976)$ states that in a typical dietary situation where protozoa account for $30 \%$, large bacteria $5 \%$ and small bacteria $65 \%$ of the microbial matter present, storage polysaccharide content would equal $17 \%$. Nocek and Tamminga (1991) estimate this microbial polysaccharide to contain approximately $25 \%$ starch. If factors other than carbohydrate availability limit microbial growth, such as a lack of nitrogen, the microbial polysaccharide content is increased because of the relatively high rate of formation of microbial polysaccharides (Hespell and Bryant, 1979). The concentration of amylolytic microbes within the rumen is dependent on the growth rate in the population, the rate of outflow from the rumen and the rate of cell death.

\section{Passage of starch and particle size reduction during digestion}

The kinetics of digestion determines the proportion of ingested nutrients that can be absorbed by the cow. The extent to which these nutrients are made 
available to the cow is the result of the competition between the processes of digestion and passage. Therefore a model designed to simulate the digestion of starch should be based around the flow of this starch through the gastrointestinal tract. Mertens (1993) described the division of the digestive tract into three compartments with unique digestive and passage properties: reticulorumen, small intestine and large intestine. The flow of undegraded starch through these compartments will depend on its particle size and density as well as dietary characteristics such as forage inclusion and dry matter intake. Soluble starch will pass out of the rumen at the rate of ruminal liquids. Smaller, denser starch particles pass out of the rumen more quickly than large particles. Several researchers have suggested a critical particle size, above which passage out of the reticulorumen is limited. Kennedy and Poppi (1984) and Pond et al. (1984) proposed particle sizes of 1.18 and $1.2 \mathrm{~mm}$, respectively. However, Murphy and Kennedy (1993) cite the concept of critical particle size as being incorrect, since not all of the small particles are equally cligible to flow from the rumen. This is because particle flow from the rumen increases as particle size is further reduced below the critical size (Smith et al., 1983). Research with maize showed that decreasing particle size resulted in increased rates of passage from the rumen (Ewing ct al., 1986).

As disintegration and hydration of starch particles occurs within the rumen, their functional specific gravity (FSG) increases. Increasing FSG of particulate matter raises the likelihood of passage from the rumen for a given particle sizc. DesBordes and Welch (1984) show the passage of particles from the rumen to be greatest at a specific gravity to be $1.2 \mathrm{~g} / \mathrm{ml}$ in steers.

Decreasing particle size and increasing the surface area to starch ratio will affect the rate of starch hydrolysis as well as the rate of passage through the digestive tract. Snow and O'Dea (1981) demonstrated that the in vitro rate of starch hydrolysis was increased for fincly ground oats, wheat and barley in comparison to the rolled grains. The in situ experiments of Galyean et al. (1981) and Thomas et al. (1988) have shown how particle size affects the disappearance rate of starch within the rumen. Large particles $(>4 \mathrm{~mm})$ were degraded more slowly than smaller particles, although progressively smaller particle size below $4 \mathrm{~mm}$ did not influence starch disappearance rate (Thomas et al., 1988).

Knowledge of the total starch content of a feedstuff or diet does not describe the distribution of the starch between different particle sizes within the digestive tract. Table 4 shows data from Galyean et al. (1981) that characterises the proportions of starch within the various particle sizes for maize following different processing methods. Generally, as the particle size decreases, so does the proportion of starch in the DM. However, high moisture maize demonstrates increasing starch content with decreasing particle size. 
The distribution of starch between different particle sizes of maize

\begin{tabular}{lcc}
\hline Processing method & Screen size & Starch. \%/DM \\
\hline Dry rolled & 6000 & 70.8 \\
& 3000 & 86.0 \\
& 1500 & 81.5 \\
& 750 & 77.9 \\
Steam flaked & 3000 & \\
& 1500 & 89.1 \\
& 750 & 84.1 \\
Dry ground & 3000 & 61.4 \\
& 1500 & 89.4 \\
High moisture & 750 & 83.2 \\
& & 74.3 \\
& 3000 & 76.4 \\
& 1500 & 80.0 \\
\hline
\end{tabular}

Galyean et al., 1981

FACTORS INFLUENCING THE NATURE OF STARCH DIGESTION IN THE RUMEN OF THE LACTATING DAIRY COW

Starch source

Variety. In addition to the variation in the total starch content observed for individual feedstuffs, the chemical and physical characteristics of the starch may also differ. Both variety and species of the cereal grains influence the chemical composition of the starch (Table 1) and hence its susceptibility to digestion in the rumen. Investigations into sorghum hybrids have provided a good example of the relations between genotype and in vitro starch degradation (Hibberd et al., 1985; Streeter et al., 1990).

Table 5 shows that hydrolysis of waxy grain is more complete and hence there is a higher DM disappearance and gas production from in vitro fermentation. Streeter et al. (1990) suggest that the waxy variety may have less peripheral endosperm, which itself contains small starch granules embedded in a dense amorphous, slowly degradable protein matrix.

Recent in situ cvaluation of different maize varieties has also shown the significant effects of genotype on starch digestion. Verbic et al. (1995), Philippeau and Michalet-Doreau (1998), and Philippeau et al. (1999) have all reported large 
variations for starch degradation between dent and flint phenotypes. Philippeau and Michalet-Doreau (1998) and Philippeau et al. (1999) describe the physical differences between the two maize varieties according to the vitreousness of the endosperm. Dent maize displays less vitreous endosperm surrounding the floury endosperm. Using a mass method described by Philippeau and Michalet-Doreau (1997) vitreousness can be quantified and dent maize displayed a vitreousness of 40.3 compared with $55.4 \%$ for flint corn.

TABLE 5

In vitro dry matter (DM) disappearance and gas production for two varieties of sorghum grain

\begin{tabular}{lccc}
\hline & $\begin{array}{c}\text { Waxy sorghum } \\
\text { starch }\end{array}$ & $\begin{array}{c}\text { Normal sorghum } \\
\text { starch }\end{array}$ & Waxy/ Normal \\
\hline DM disappearance (in vitro), \% & 39.85 & 37.45 & 106.4 \\
Gas production (in vitro), \% & 97.7 & 80.45 & 121.4 \\
\hline
\end{tabular}

Streeter et al., 1990

The variation in effective starch degradability between the two genotypes in Table 6 was due to the large difference in the rapidly degradable fraction. This can also be seen in Figure 4 where data from the same investigation show the disappearance of starch over time. Figure 4 shows that the rate of starch disappearance for the first $24 \mathrm{~h}$ of the incubation was similar for both dent and flint maize starches. A relative increase in rate of digestion for the flint maize starch during the later period of incubation led to similar percentages of starch disappearance following $48 \mathrm{~h}$ of in situ incubation. The starch granules of the vitreous endosperm are less susceptible to degradation by enzymatic hydrolysis due to association with a continuous protcin matrix. Philippeau et al. (1999) examined variation for the in situ degradation of 8 dent and 6 flint maize varieties. The range in the effective degra-

TABLE 6

In situ degradation characteristics for dent and tlint maize starches

\begin{tabular}{cccccc}
\hline $\begin{array}{c}\text { Undegradabie } \\
\text { fraction } \\
\%\end{array}$ & $\begin{array}{c}\text { Rapidly degradable } \\
\text { fraction (a) } \\
\%\end{array}$ & $\begin{array}{c}\text { Slowly degradable } \\
\text { fraction (b) } \\
\%\end{array}$ & $\begin{array}{c}\text { Degradation } \\
\text { constant rate (c) } \\
\text { h }\end{array}$ & $\begin{array}{c}\text { Effective } \\
\text { degradability } \\
\%\end{array}$ \\
\hline Dent & 0 & 34.8 & 65.2 & 0.069 & 72.3 \\
Flint & 0 & 9.9 & 90.1 & 0.068 & 61.6 \\
& NS & $\mathrm{P}<0.001$ & $\mathrm{P}<0.001$ & $\mathrm{NS}$ & $\mathrm{P}<0.001$ \\
\hline
\end{tabular}

NS - Not Significant

1 effective degradability was calculated using $a+b c /(c+k)$, where $k=$ outflow rate (assumed to be 0.05/h) adapted from Philippeau and Michalet-Doreau, 1998 
dability between varieties of the same phenotype was four times greater in the dent grain $(19.6 \%)$ than that of the flint grain $(5.6 \%)$ which reflected the significantly different $(\mathrm{P}=0.0001)$ range in vitreousness between the two phenotypes. Vitreousness is strongly correlated with grain density $\left(r^{2}=0.71\right.$; Philippeau et al., 1999) and therefore grain density could be used as a practical mechanism by which to predict the degradability characteristics of maize starch.

Schroeder et al. (1998) examined the effects of waxy maize in comparison with dent maize on the concentration of rumen VFA in dairy cows. Table 7 summarises these data and shows that significant difference in ruminal acetate, isobutyrate and isovalerate concentrations were observed. However the decline in these individual VFA concentrations with the inclusion of waxy maize in the diet did not continue beyond the point where waxy maize constituted $50 \%$ of the maize inclusion.

Feng et al. (1995) hypothesised that differences in ruminal starch degradation would occur between barley varieties in a similar manner to those described for sorghum and maize. However, between the two varieties chosen for the study, no significant differences were observed.

TABLE 7

Least square means for rumen VFA concentration of Holstein cows fed varying proportions of waxy and flint maizc

\begin{tabular}{lccc}
\hline Rumen VFA. mM & Waxy maize 0\% & Waxy maize 50\% & Waxy maize 100\% \\
\hline Acctate & $75.33^{\mathrm{a}}$ & $68.03^{\mathrm{h}}$ & $68.43^{\mathrm{a}} \mathrm{h}$ \\
Propionate & 29.43 & 27.60 & 27.71 \\
Butyrate & 16.55 & 15.20 & 15.39 \\
Isobutyrate & $1.76^{\mathrm{h}}$ & $1.54^{\mathrm{h}}$ & $1.67^{\mathrm{a}}$ \\
Valerate & 4.55 & 4.21 & 4.23 \\
Isovalerate & $2.74^{\mathrm{h}}$ & $2.38^{\mathrm{a}}$ & $2.58^{\mathrm{a}, \mathrm{h}}$ \\
Total & 130.36 & 118.96 & 120.01 \\
A:P ratio & 2.62 & 2.53 & 2.56 \\
\hline
\end{tabular}

means within a row without common superscripts differ $(\mathrm{P}<0.05)$; Schroeder et al., 1998

Feedstuffs. Several reviews have comprehensively summarised starch type and its effects on starch digestion in ruminants (Owens et al., 1986; Rooncy and Pflugfelder, 1986; Theurer, 1986; Huntington, 1997). In general, cereal starches are more easily degraded than root and tuber starches, while legume starches have intermediate digestibility. Herrera-Saldana et al. (1990b) described the starch degradability for five cercal grains; maizc, sorghum, wheat, barley and oats. The investigation led to a ranking of the five grains for starch degradation in situ and in vitro. Both the in situ and in vitro data gave the same ranking of the grains in terms of starch degradability, which indicates that in vitro data can represent starch de- 
gradabilities as they occur in the rumen. Oats were most easily degraded followed by wheat, barley, maize and finally sorghum. Huntington (1997) reviewed in vivo data for a nine-year period and obtained a similar ranking of the cercal grains based on total tract digestibility. Based on in situ data, De Visser (1993) showed that $42 \%$ of the insoluble starch in maize and sorghum grain can escape rumen digestion, compared with $8 \%$ for wheat and barley, assuming a passage rate constant applicable to high yielding dairy cows. After reviewing the available literature, Waldo (1973) also concluded that sorghum starch is the most resistant to digestion in the rumen.

The data examined so far for the determination of the effects of starch source on its digestive properties has been associated mainly with non-lactating cows or steers. This raises the question as to its ability to represent the fate of starch in the high yielding dairy cow. The data from lactating dairy cows in Table 8 show that the digestibility of similarly processed starches can vary widely depending on starch source. For dry ground or rolled cereals the digestibility within the rumen varied from below $50 \%$ with sorghum and maize to over $80 \%$ for barley. Figure 5 clearly shows that maize starches display a lower ruminal digestibility for a given starch intake when compared to wheat and barley. However, data for intakes of steam flaked maize starch greater than $5 \mathrm{~kg} \mathrm{day}^{-1}$ are not available. At intakes of steam flaked maize starch between 3 and $5 \mathrm{~kg} \mathrm{day}^{-1}$ the rate of increase in ruminal digestion is greater than the increase in starch intake. Extrapolation of this relationship suggests relatively high digestibility of steam flaked maize starch at higher starch intakes, especially compared to barley and wheat starches. Therefore more digestibility data is needed involving steam flaked maize starch fed at intakes of $5 \mathrm{~kg}$ day ${ }^{-1}$ and above.

Table 9 summarises rumen fermentation data from the appendix where different starch sources were fed to lactating dairy cows. Although information for wheat is presented, it is confounded by the lack of data from a range of studies. Maize, sorghum and barley starches were present in the diet at similar concentrations (27-30\% diet DM), which allows for good comparison. Mean rumen $\mathrm{pH}$ tended to be lower for barley $(5.69 \pm 0.08)$ than for maize $(6.04 \pm 0.25)$ or sorghum $(5.95 \pm 0.07)$. This is the result of the more complete ruminal degradation of starch from barley and the subsequent accumulation of acid in the rumen. The mean quantity of lipogenic VFAs relative to glucogenic VFAs would also seem to be lower for barley based rations. This is a result of an increased propionate concentration at the expense of acetate concentration with a relatively constant butyrate concentration.

\section{Feedstuff processing}

Unlike shecp and goats, cattle are not able to effectively utilise whole cereal grains (Halc, 1973; Ørskov, 1986). Whole grain with an intact pericarp is largely 
Mean digestibility coefficients for the digestion of different starch sources in lactating dairy cows

\begin{tabular}{|c|c|c|c|c|c|c|c|c|c|c|c|c|c|c|}
\hline & & & & & & & & Dig & stibility & & & & & \\
\hline & & & & Ru & nen & Po & strumen & & & & & Tota & tract & \\
\hline grain & processing & $\begin{array}{r}\text { starc } \\
\mathrm{k}\end{array}$ & $\begin{array}{l}h \text { intake } \\
\text { day }\end{array}$ & $\%$ & atake & $\%$ & intake & $\%$ et & $\begin{array}{l}\text { atering } \\
\text { SI }\end{array}$ & & $\begin{array}{l}\text { total } \\
\text { estion }\end{array}$ & $\%$ i & take & references \\
\hline Maize & Dry ground & 8.03 & +-1.80 & 47 & +-7 & 47 & +-8 & 89 & +-6 & 50 & +-8 & 94.4 & +-2.5 & $2,4,5,6,7,8,13,20,22$ \\
\hline & $\begin{array}{l}\text { Dry rolled } \\
\text { High moisture }\end{array}$ & 4.92 & & 50 & & 26 & & 47 & & 33 & & 76.6 & & $14,16,20$ \\
\hline & $\begin{array}{l}\text { ground or rolled } \\
\text { Steam flaked }\end{array}$ & 8.55 & & 83 & & 13 & & 82 & & 13 & & 96.9 & & 20 \\
\hline & or rolled & 4.86 & +-1.77 & 50 & +-17 & 43 & +-12 & 89 & +-7 & 50 & +-18 & 93.8 & +-5.0 & $12,14,16,19$ \\
\hline Barley & Dry rolled & 6.53 & +-1.73 & 83 & +-3 & 14 & +-1 & 80 & +-12 & 14 & +-1 & 94.2 & +-4.1 & $1,3,17,22$ \\
\hline & Steam rolled & 7.83 & +-1.00 & 76 & +-2 & 20 & +-1 & 84 & +-3 & 21 & +-1 & 96.6 & +-0.3 & 2,13 \\
\hline Wheat & Dry rolled & 3.70 & & 66 & & 33 & & 98 & & 35 & & 99.3 & & 15 \\
\hline & Steam rolled & 3.50 & & 71 & & 29 & & 97 & & 30 & & 99.3 & & 15 \\
\hline Sorghum & $\begin{array}{l}\text { Dry rolled } \\
\text { Steam flaked }\end{array}$ & 6.11 & +-1.05 & 48 & +-5 & 37 & +-8 & 71 & +-10 & 44 & +-8 & 84.4 & +-4.2 & $1,3,10,11,17,18$ \\
\hline & or rolled & 6.79 & +-1.12 & 73 & +-4 & 25 & +-4 & 92 & +-0.3 & 25 & +-4 & 96.8 & +-2.1 & $10,11,12,17,18$ \\
\hline Barley + Peas & & 3.29 & & 89 & & 10 & & 94 & & 10 & & 99.3 & & 9 \\
\hline Barley + Maize & $\begin{array}{l}\text { Steam rolled + } \\
\text { dry ground }\end{array}$ & 7.00 & & 65 & & 29 & & 80 & & 30 & & 94.2 & & 13 \\
\hline
\end{tabular}

+ - figures are standard deviations where means are the result of 4 or more measurements

References:

1. Herrera-Saldana and Huber, 1989

2. McCarthy, Klusmeyer, Vicini, Clark and Nelson, 1989

3. Herrera-Saldana, Gomez-Alarcon, Torabi and Huber, 1990

4. Klusmeyer, McCarthy, Clark and Nelson, 1990

5. Cameron, Klusmeyer, Lynch, Clark and Nelson, 1991

6. Klusmeyer, Lynch, Clark and Nelson, 1991

7. Klusmeyer, Lynch, Clark and Nelson, 1991

8. Lynch, Klusmeyer, Cameron, Clark, Nelson, 1991

9. Palmquist, Wesibjerg and Hvelplund, 1993
10. Poore, Moore, Eck, Swingle and Theurer, 1993

11. Poore, Moore, Swingle and Brown, 1993
12. Chen, Huber, Theurer, Swingle, Simas, Chan, Wu and Sullivan, 1994

13. Overton, Cameron, Elliot, Clark and Nelson, 1995

15. Espindola, DePeters, Fadel, Zinn and Perez-Monti, 1997

16. Joy, DePeters, Fadel and Zinn, 1997

17. Santos, Huber, Theurer, Swingle, Wu. Simas, Chen, Chan, Santos and DePeters, 1997

18. Simas, Huber, Theurer, Chen, Santos and Wu, 1997

19. De Visser, Klop, Van Der Meulen and Van Vuuren, 1998

20. Knowlton, Glenn and Erdman, 1998

21. Schroeder, Marx, Park, 1998

22. Sutton and Oldham, unpub. 


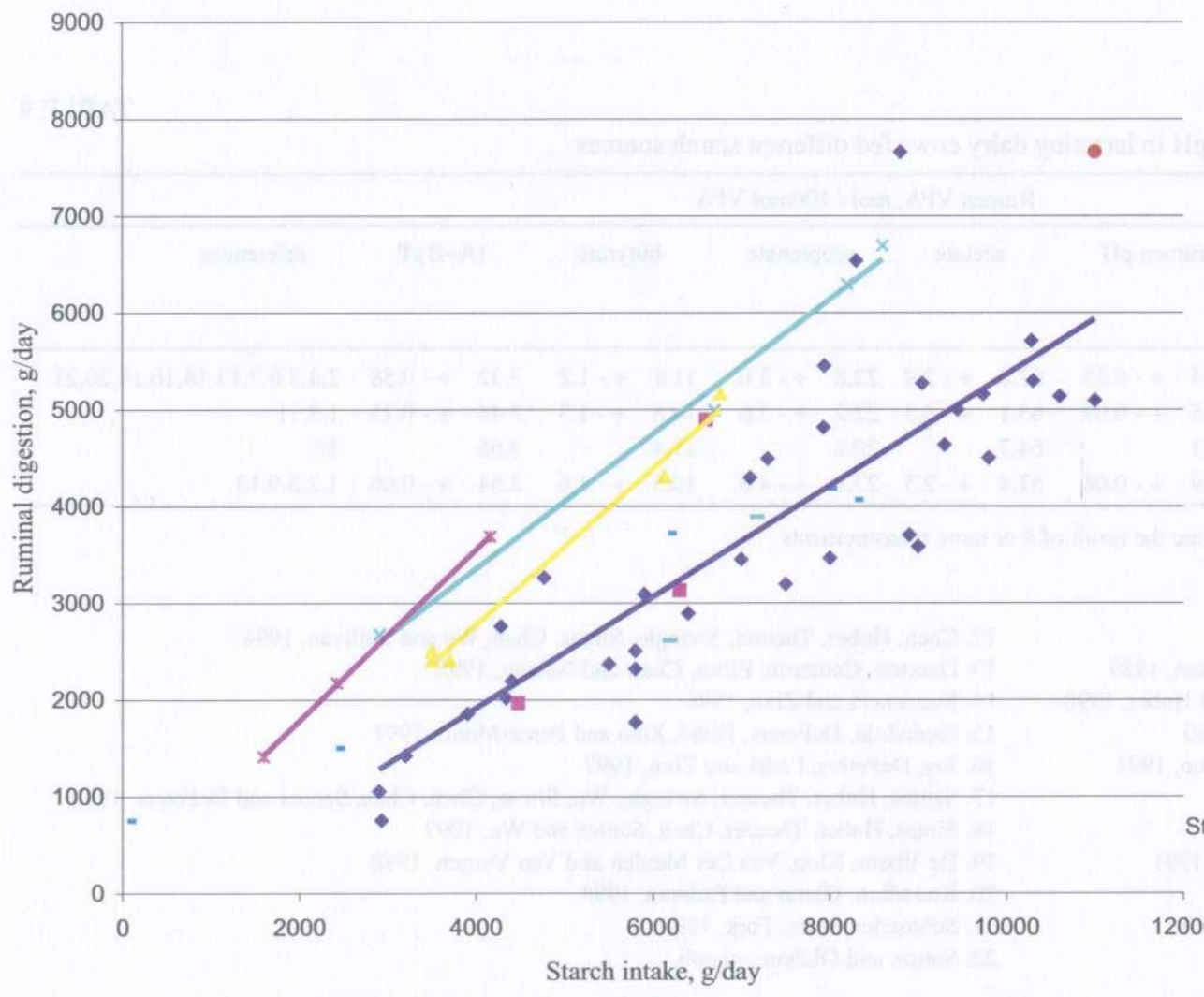

- Dry ground maize

- Dry rolled maize

- Steam flaked maize

$x$ Dry rolled barley or wheat

* Steam rolled barley or wheat

- Dry rolled sorghum

+ Steam flaked sorghum

- Mixed barley, maize, peas

- High moisture maize

- Liniowy (Steam flaked maize)

- Liniowy (Dry ground maize)

- Liniowy (Dry rolled barley or wheat)

- Liniowy (Steam rolled barley or wheat)

Dry ground maize $y=0.5768 x-802.68$

$$
R^{2}=0.8127
$$

Steam flaked maize $y=1.193 x-2606$

$$
R^{2}=0.8852
$$

Dry rolled wheat or barley $y=0.9489 x-756.9$

$$
R^{2}=0.9223
$$

Steam rolled barley or wheat $y=0.8248 x-451.13$

$$
R^{2}=0.9991
$$

Figure 5. Relationship between ruminal starch digestion and starch intake in lactating dairy cows 
Rumen VFA molar proportions and rumen $\mathrm{pH}$ in lactating dairy cows fed different starch sources

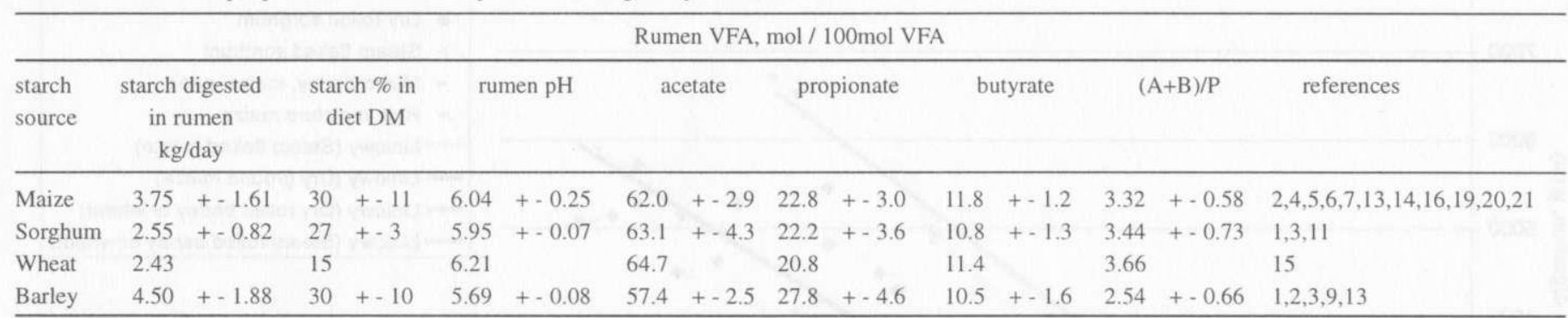

+ - figures are standard deviations where means are the result of 4 or more measurements

\section{References:}

1. Herrera-Saldana and Huber, 1989

2. McCarthy, Klusmeyer, Vicini, Clark and Nelson, 1989

3. Herrera-Saldana, Gomez-Alarcon, Torabi and Huber, 1990

4. Klusmeyer, McCarthy, Clark and Nelson, 1990

5. Cameron, Klusmeyer, Lynch, Clark and Nelson, 1991

6. Klusmeyer, Lynch, Clark and Nelson, 1991

7. Klusmeyer, Lynch, Clark and Nelson, 1991

8. Lynch, Klusmeyer, Cameron, Clark, Nelson, 1991

9. Palmquist, Wesibjerg and Hvelplund, 1993

10. Poore, Moore, Eck, Swingle and Theurer, 1993

11. Poore, Moore, Swingle and Brown, 1993
12. Chen, Huber, Theurer, Swingle, Simas, Chan, Wu and Sullivan, 1994

13. Overton, Cameron, Elliot, Clark and Nelson, 1995

14. Plascencia and Zinn, 1996

15. Espindola, DePeters, Fadel, Zinn and Perez-Monti, 1997

16. Joy, DePeters, Fadel and Zinn, 1997

17. Santos, Huber, Theurer, Swingle, Wu, Simas, Chen, Chan, Santos and DePeters, 1997

18. Simas, Huber, Theurer, Chen, Santos and Wu, 1997

19. De Visser, Klop, Van Der Meulen and Van Vuuren, 1998

20. Knowlton, Glenn and Erdman, 1998

21. Schroeder, Marx, Park, 1998

22. Sutton and Oldham, unpub. 
or entirely resistant to bacterial attachment within the rumen (Beauchemin et al., 1994). Processing grain causes varying degrees of gelatinisation, retrogradation and dextrinisation of the starch (Rooney and Pflugfelder, 1986). Processing and its effects on site, rate, and extent of digestion has been reviewed in several instances (Hale, 1973; Waldo, 1973; Ørskov, 1986; Theurer, 1986). Hale (1973) lists 18 such methods and classificd them as either dry or wet processing methods. For each method listed there are variations in the technique used that may cause the starch to behave differently upon digestion.

Nocek and Tamminga (1991) catagorise cereal grain processing techniques into physical and physiochemical methodologies. Physical processing is associated with cracking, grinding, rolling or pelleting of dry grains. Physiochemical processes involve application of heat and water to the grains which causes gelatinisation. Both the physical and physiochemical processes allow the starch to be degraded more rapidly following ingestion. Such processing methods produce starch that is more susceptible to enzyme attack due to disruption of the protein matrix which characteristics the endosperm of the cereal grains. Preston et al. (1993) studied the in vitro degradability of sorghum grain and demonstrated a positive relationship between starch gelatinisation and degradation to the point where $60 \%$ of the total starch was gelatinised. As well as altering the susceptibility to enzymatic attack, the physical changes associated with processed grain can directly influence the passage of starch through the digestive tract. This in turn affects the rate, extent and site of starch digestion. As the degree of physical processing increases, the passage rate also increases. Knowlton et al. (1996) demonstrated how decreasing particle size (ground maize vs cracked maize) reduced the number of ruminal contractions in early lactation cows. Figure 6 displays the change in particle size distribution associated with different processing methods of maize (Yu et al., 1998). Steam flaking and rolling of maize increases the proportion of particles over $4 \mathrm{~mm}$ in diameter mainly at the expense of the very smallest particle sizes. Also, the effect of steam flaking on the degradation of starch within the rumen is not consistent for different feed particle sizes. Galyean et al. (1981) and Thomas et al. (1988) showed that the steam flaking of maize grain produced the greatest increase for in situ starch disappearance at large particle sizes.

Table 8 shows mean digestibility coefficients for different starch sources following various processing methods. Digestibility coefficients are not consistent among grain types for the change in digestibility associated with similar processing methods. Digestibility of maize starch in the rumen did not differ between dry grinding and steam flaking or steam rolling. However, the rumen digestibility of high moisture maize starch was greatly increased in comparison to dry grinding or rolling (Knowlton et al., 1998). Sorghum starch showed much more of a response to steam flaking and rolling, as digestibility in the rumen increased from 48 to $73 \%$. For barley and wheat starches, steam processing does not seem to impact on 
rumen degradability. The linear regressions displayed in Figure 5 highlight the effect of processing on the rumen digestibility as starch intake increases. The effect of steam flaking or rolling does not appear to be influenced by level of starch intake. When compared to dry grinding, steam flaking or rolling of maize produced highly variable results. This is principally the result of different densities of steam flaked maize, the effect of which can be seen in Figure 7. Table 8 shows that total tract starch digestion was similar for all starch sources and processing methods except for dry rolled maize and sorghum. Both of these starches displayed relatively low overall total tract starch digestion when dry rolled (Figure 6). Indeed Ørskov (1986) showed that sorghum and maize benefit more in terms of overall digestibility from processing than other grains.

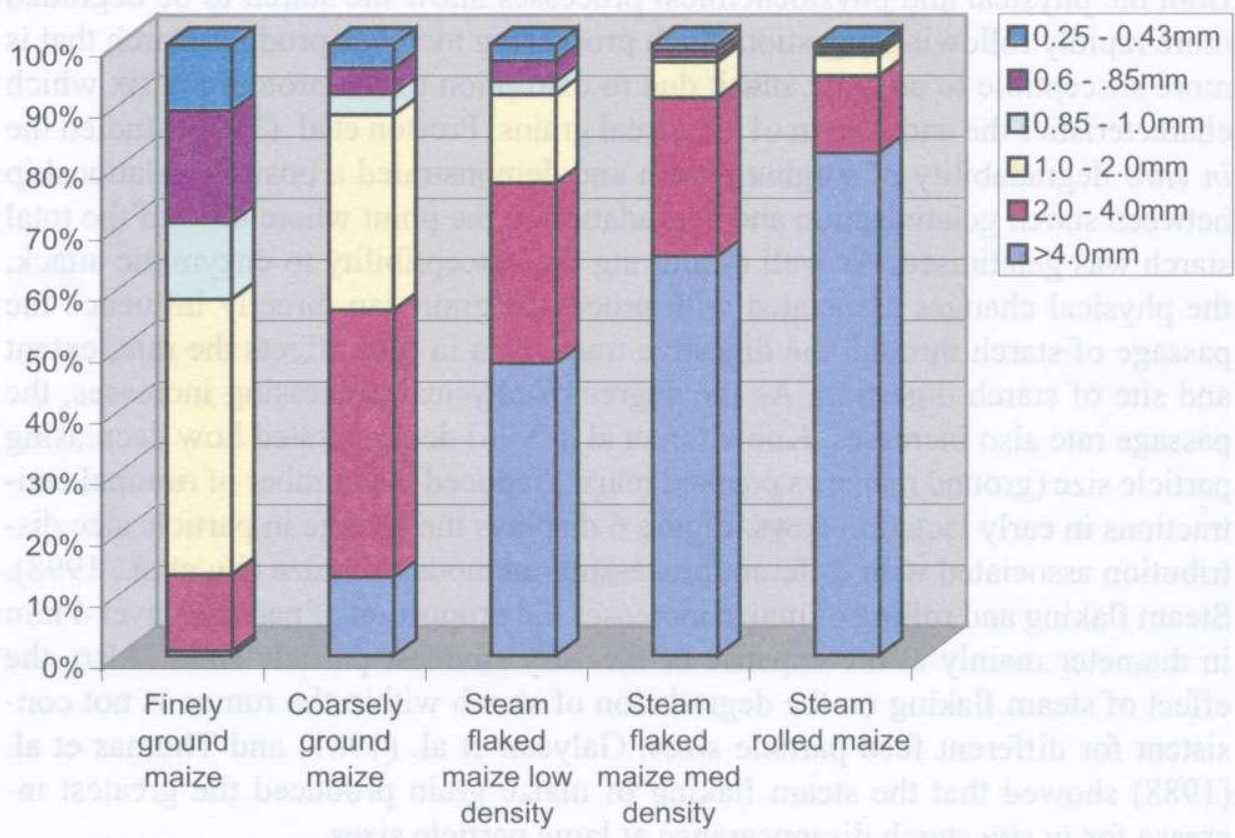

Figure 6. Particle size distribution of processed maize; data from Yu et al., 1998

Zinn (1990) showed that altering steaming time during the processing of maize grain could affect rumen digestibility of starch. In this instance, a quadratic effect was observed $(\mathrm{P}<0.05)$, and starch digestibility in the rumen of maize steamed for $47 \mathrm{~min}$ was $7 \%$ less than that of maize steamed for 34 or $67 \mathrm{~min}$. These data also show the need for caution when comparing digestibility data between studies, from different processing methods. 


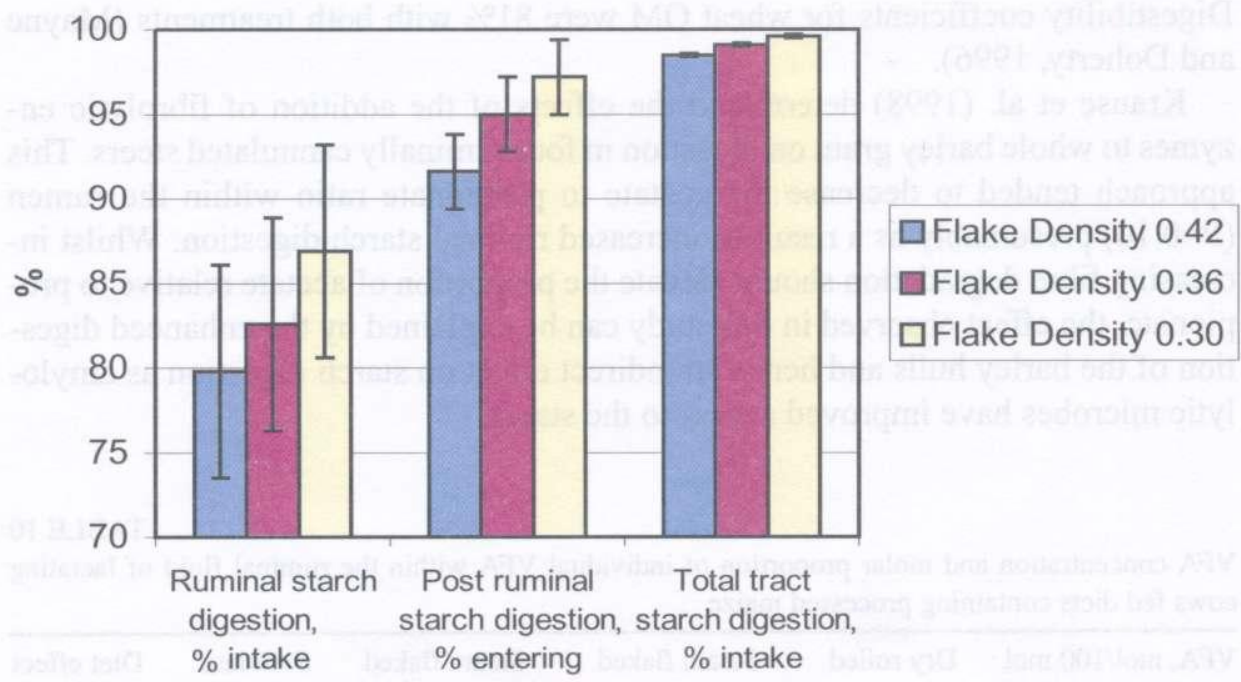

Figure 7. The influence of density of steam flaked sorghum on digestibility in feedlot steers; data from Zinn, 1990b

Joy et al. (1997) investigated the concentration of VFA within the rumen for steam flaked and dry rolled maize. The results are shown in Table 10. Despite there being no effect of treatment on the extent of ruminal starch digestion, steam flaking increased the molar percentage of propionate whilst concentrations of acetate and isovalerate declined. This could be the result of a difference in the rate of starch fermentation in the rumen, although this was not measured in this study (Joy et al., 1997).

The use of chemical treatments such as sodium hydroxide $(\mathrm{NaOH})$ disrupts the pericarp of the grain by partial hydrolysis of hemicellulose and lignin. It also causes swelling of the outer starch granules so that rumen bacteria gain access to the starchy endosperm. However, in a study by Miron et al. (1997), starch digestibility in the reticulorumen of steers for $\mathrm{NaOH}$ treated sorghum grain was only $32 \%$ compared with $47 \%$ for ground sorghum. Total tract digestibility for the two treatments was $68 \%$ for $\mathrm{NaOH}$ treatment $(4 \% \mathrm{NaOH}$ per $\mathrm{kg} \mathrm{DM})$ and $90 \%$ for the ground sorghum. These data support the principal that total tract digestibility of starch is related more to ruminal (Figure 8) digestion than intestinal digestion. In a study investigating the use of $\mathrm{NaOH}(3.5 \% \mathrm{NaOH}$ per $\mathrm{kg} \mathrm{DM})$ treated wheat grain vs ground wheat, Mayne and Doherty (1996) reported no difference in the apparent digestibility of dry matter (DM) or organic matter (OM) between the two treatments for dairy cows. These data suggest that $\mathrm{NaOH}$ treatment has less effect on digestibility when used to treat sorghum than with the treatment of wheat. 
Digestibility coefficients for wheat OM were $81 \%$ with both treatments (Mayne and Doherty, 1996).

Krause et al. (1998) determined the effects of the addition of fibrolytic enzymes to whole barley grain on digestion in four ruminally cannulated steers. This approach tended to decrease the acetate to propionate ratio within the rumen $(\mathrm{P}=0.10)$ presumably as a result of increased ruminal starch digestion. Whilst increasing fibre degradation should elevate the proportion of acetate relative to propionate, the effect observed in this study can be explained by the enhanced digestion of the barlcy hulls and hence an indirect effect on starch digestion as amylolytic microbes have improved access to the starch.

TABLE 10

VFA concentration and molar proportion of individual VFA within the ruminal fluid of lactating cows fed diets containing processed maize

\begin{tabular}{lccccc}
\hline VFA, mol/100 mol & $\begin{array}{c}\text { Dry rolled } \\
\text { maize }\end{array}$ & $\begin{array}{c}\text { Steam flaked } \\
\text { maize (high } \\
\text { flake density) }\end{array}$ & $\begin{array}{c}\text { Steam flaked } \\
\text { maize (low } \\
\text { flake density) }\end{array}$ & $\begin{array}{c}\text { Standard } \\
\text { error }\end{array}$ & $\begin{array}{c}\text { Diet effect } \\
\mathrm{P}<\end{array}$ \\
\hline Acctatc (A) & $66.29^{\mathrm{a}}$ & $65.25^{\mathrm{h}}$ & $64.33^{\mathrm{b}}$ & 0.33 & 0.01 \\
Propionate (P) & $18.46^{\mathrm{h}}$ & $19.13^{\mathrm{h}}$ & $20.38^{\mathrm{a}}$ & 0.26 & 0.01 \\
Butyrate & 12.36 & $12.72^{\mathrm{h}}$ & 12.40 & 0.16 & 0.30 \\
Isovalerate & $1.45^{\mathrm{a}}$ & $1.42^{\mathrm{at}}$ & $1.36^{\mathrm{h}}$ & 0.03 & 0.04 \\
Valerate & 1.43 & 1.47 & 1.53 & 0.03 & 0.19 \\
Total VFA (mM) & 104.29 & 102.11 & 112.22 & 3.66 & 0.14 \\
A:P & $3.60^{\mathrm{a}}$ & $3.43^{\mathrm{a}}$ & $3.17^{\mathrm{h}}$ & 0.06 & 0.01 \\
\hline
\end{tabular}

a.b.c means with different superscripts differ $(\mathrm{P}<0.05)$

adapted from Joy ct al., 1997

The effects of formaldchyde treatment of starch sources on its subsequent digestion have been inconsistent. With sheep, Morgan et al. (1989) found that treatment of barlcy with formaldehyde had no effects on postruminal starch delivery, whilst Fluharty and Loerch (1989) demonstrated a 42\% reduction in ruminal starch digestion for ground maize treated with $2 \%$ formaldehyde in sheep. Whilst formaldehyde can limit ruminal starch digestion, acid in the abomasum destroys the cross bonding which itself prevented granule swclling, and therefore postruminal starch digestion is unaffected. Table 11 shows that the result of formaldchyde treatment is a shift in the site of digestion away from the rumen, with total tract starch digestion remaining constant (Fluharty and Loerch, 1989). Indeed, McAllister et al. (1992) demonstrated an increase in total tract starch digestion following treatment with $0.11 \%$ formaldehyde. 


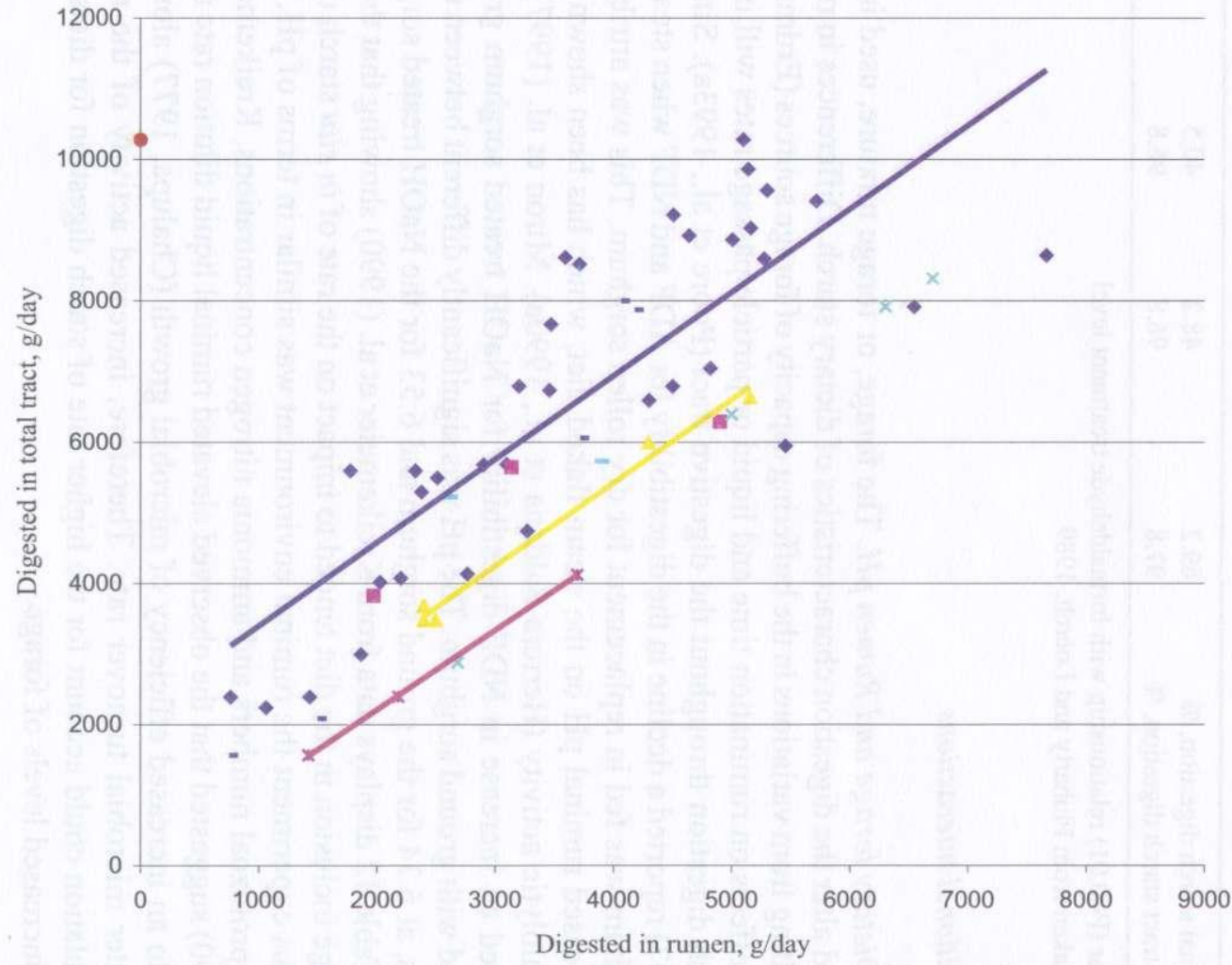

- Dry ground maize

- Dry rolled maize

A Steam flaked maize

$x$ Dry rolled barley or wheat

* Steam rolled barley or wheat

- Dry rolled sorghum

+ Steam flaked sorghum

- Mixed barley + maize, barley + peas

- High moisture maize

- Liniowy (Dry ground maize)

- Liniowy (Steam flaked maize)

- Liniowy (Steam rolled barley or wheat)

Dry ground maize $y=1.272 x+2711.6$

$$
R^{2}=0.7725
$$

Steam flaked maize $y=1.0057 x+1480.6$

$$
R^{2}=0.8797
$$

$$
\begin{gathered}
y=1.1473 x+666.29 \\
R^{2}=0.9996
\end{gathered}
$$

Figure 8 . Relationship between total tract and ruminal digestion of starch in lactating dairy cows 
Processing effects on total DMI are inconsistent, with some reports indicating increases in intake (Chen et al., 1994) associated with steam flaking compared with dry rolling of sorghum, and others showing no effect (Simas et al., 1997) or even a decrease in intake (Olivera ct al., 1993). Reasons for this inconsistency are unclear, but Simas et al. (1997) suggest that animal factors such as stage of lactation and body condition score or environmental factors could influence the DMI response.

TABLE 11

Effect of formaldehyde-treated maize on nutrient digestion by sheep

\begin{tabular}{lcccc}
\hline \multicolumn{5}{c}{ Formaldehyde treatment, \% } \\
\hline & 0 & 1 & 2 & SE \\
\hline Ruminal starch digestion, \% & 69.2 & 48.2 & 40.5 & $4.5^{\mathrm{a}}$ \\
Total tract starch digestion, \% & 97.8 & 96.8 & 96.8 & 0.3 \\
\hline
\end{tabular}

"linear $(\mathrm{P}<0.01)$ relationship with formaldehyde treatment level

data taken from Fluharty and Loerch, 1989

\section{Nutritional interactions}

Dietary forage and Rumen $\mathrm{pH}$. The forage, or forage mixture, used in the diet could alter the digestion characteristics of dietary starch. Differences in rumen $\mathrm{pH}$ resulting from variations in the buffering capacity of forage sources (Erdman, 1988) and effects on rumination time and liquid or particle passage rates will impact on starch digestion throughout the digestive tract (Poore et al., 1993a). Simas et al. (1997) reported a decline in the digestibility for ADF and NDF when steam flaked sorghum was fed in replacement for dry rolled sorghum. This was attributed to a decreased ruminal $\mathrm{pH}$ on the steam flaked diet, which has been shown to affect cellulolytic activity (Herrera-Saldana et al., 1990a). Miron et al. (1997) demonstrated an increase in NDF digestibility for $\mathrm{NaOH}$ treated sorghum grain compared with ground sorghum. The $\mathrm{pH}$ was significantly different between these two diets, at 6.34 for the ground sorghum and 6.53 for the $\mathrm{NaOH}$ treated sorghum.

Table 12 displays data from Kreikemeier et al. (1990) showing that the level of forage inclusion in the diet tended to impact on the rate of in situ starch digestion. In this experiment the ruminal environment was similar in terms of $\mathrm{pH}$, bacterial and protozoal numbers and ammonia nitrogen concentrations. Kreikemeier et al. (1990) suggested that the observed elevated ruminal liquid dilution rate may have led to an increased efficiency of microbial growth (Chalupa, 1977) along with a greater microbial turnover rate. Therefore, increased activity of the microbial population could account for the higher rate of starch digestion for diets containing increased levels of forage. 
TABLE 12

Effect of forage inclusion level on the rate of in situ ruminal starch digestion

\begin{tabular}{ccccc}
\hline \multicolumn{5}{c}{ Forage, \% $(50 \%$ maize silage $+50 \%$ lucerne hay $)$} \\
\hline & 0 & 5 & 15 & SE \\
\hline Rate of starch digestion, $\% / \mathrm{h}$ & 12.8 & 13.3 & 15.0 & 1.1 \\
\hline
\end{tabular}

data from Kreikemeier et al., 1990

The studies summarised in Table 8 generally include lucerne hay as the forage source. Under UK conditions, grass silage, maize silage or a mixture of both would form the principal forage sources for housed dairy cows whilst grazed grass can contribute a large part of the diet during the summer. In general, grass silage based diets would tend to be lower in both crude protein and rumen degradable protein than lucerne silage, which would in turn be lower in protein than fresh grass. These differences in protein content could affect starch digestion (see next section). Also, the inherent buffering capacity of these different forage sources within the diet will affect the ruminal pH (Erdman, 1988) and consequently the rate of fibre and possibly starch digestion. A research effort is therefore needed to examine starch digestion where the forage sources are more typical of UK rations.

Whilst the influence of $\mathrm{pH}$ on the microbial population structure has already been discussed, particularly in terms of the effect on protozoa, rumen $\mathrm{pH}$ may also affect the rate of starch degradation via an effect on enzymic activity. Amylolytic enzymes secreted by the rumen bacteria have not been studied extensively in terms of their activity over a range of $\mathrm{pH}$ values. However, McWethy and Hartman (1977) purified an $\alpha$-amylase from Bacteroides amylophilus and reported a $\mathrm{pH}$ optimum of 6.3 along with a pH stability range between 4.8 and 7.5. Cone and Vlot (1990) showed that a variety of bacterial amylases had $\mathrm{pH}$ optima between 4.5 and 8.0. Colcman (1986) showed that amylase activity was greatest at $\mathrm{pH} 6.0$ when derived from protozoa and between 5.6 and 6.4 for amylase of bacterial origin. The $\mathrm{pH}$ optima are within the range of $\mathrm{pH}$ experienced in the rumen under most dietary situations including those of high starch diets. It is therefore unlikely that any major effect on starch degradation rate would be seen due to acidic conditions in the rumen. This is a direct result of the low $\mathrm{pH}$ tolerance of the amylolytic bacteria and the high level of activity of their enzymic secretions under these conditions. The less acid tolerant protozoa may be depleted in number below a certain threshold $\mathrm{pH}$ (Slyter et al., 1970), which may lead to an increased availability of starch to the bacteria and a more rapid fermentation of this starch. Therefore any effect of $\mathrm{pH}$ on starch fermentation in the rumen is principally via a change in the structurc of the microbial population, and the effect on fibre degradation may be more pronounced than the direct effects on starch degradation. 
Dietary protein and non-protein nitrogen availability. Where ruminal nitrogen concentration limits microbial growth, the extent of starch degradation in the rumen may be decreased as total amylolytic activity of the microbial mass is depressed. However, Klusmeyer et al. (1990) did not observe any increase in apparent ruminal or post-ruminal starch digestibility as dietary crude protein concentration increased from 11 to $14.5 \%$. Including urea at $0.75 \%$ of dietary DM did not affect starch digestibility throughout the digestive tract in lactating cows (Camcron et al., 1991).

Dietary fat. Simas et al. (1997) investigated the influence of different fat sources on sorghum starch digestibility in lactating cows. When dry rolled sorghum was fed, starch digestibility tended to be lower where tallow was included in the diet in replacement of cottonseed oil. Palmquist et al. (1993) observed no difference in ruminal starch digestibility when $5 \%$ added fat was included in the diet. When Klusmeyer et al. (1991b) fed lactating cows calcium salts of long chain fatty acids (Ca LCFA), a ruminally inert form of fat, at $4 \%$ of dietary DM, cows tended to digest a smaller percentage ( 40.8 vs $47.3 \%$ ) of starch in the rumen. However, both the subsequent digestibility of the starch passing to the duodenum and total tract starch digestibility were raised where Ca LCFA was fed. Klusmeyer ct al. (1991b) suggested that the reduced feed intake observed where cows were fed Ca LCFA could have caused such results. However, reduced feed intake generally lowers passage rate of digesta and increases the ruminal $\mathrm{pH}$. This would increase rumen starch degradation.

Antinutritional factors. Antinutritional factors present in the diet can impact directly on starch digestion. Polyphenolic compounds, which include the tannins, are present in potato tubers and in certain varieties of sorghum. Such $\alpha$-amylase inhibitors are present as inhibitors of plant $\alpha$-amylases in order to regulate germination, and for brown sorghum varicties they act as a deterrent to crop destruction by birds and snails. However, whilst such compounds can be agronomically beneficial, they may be nutritionally disadvantageous due to a negative influence on the digestion of starch in the rumen (Hahn et al,, 1984). Hibberd et al. (1985) showed that tannins in sorghum do not influence ruminal starch degradability to a great extent.

Feed additives. Chamberlain et al. (1993) showed that feeding starch to sheep produced a greater and more prolonged decrease in rumen $\mathrm{pH}$ than when feeding sugars. Therefore, due to the risk of ruminal acidosis, buffers are often used in an attempt to limit the $\mathrm{pH}$ decrease within the rumen, following high levels of starch intake. Typical buffers are sodium bicarbonate, calcium carbonate or magnesium oxide. However, the mechanism by which these compounds work may not be as 
initially proposed. Following a review of the literature, Russell and Chow (1993) concluded that dietary buffers had little effect on ruminal $\mathrm{pH}$, due to the overlying effect of $\mathrm{CO}_{2}$ transfer from the blood. They suggest that the increased water consumption associated with the salt intake led to an increased dilution rate and a higher level of feed starch escaping rumen degradation. However, Zinn and Borques (1993) did not find any effect on the sitc or extent of starch digestion in steers fed sodium bicarbonate.

The use of in feed antibiotics to change the microbial population of the rumen has become an accepted method of increasing digestive efficiency in those countrics where the method is licensed. One such group of antibiotics is the ionophores. They are active against gram positive bacteria and can significantly reduce methane production whilst raising the level of propionate production. The effect of feeding ionophores on the digestion of starch seems to be unpredictable with both the ionophore and starch source influencing the results of feeding trials. Kung et al. (1992) showed that there was an interaction $(\mathrm{P}<0.05)$ between starch source and the ionophore lysocellin. In vitro organic matter digestion on maize based diets tended to increase, whilst on barley based diets organic matter digestion tended to decrease, with lysocellin inclusion. More research is needed in order to gain an improved understanding as to the influence of ionophores on starch digestion in the dairy cow.

\section{Management}

Sutton et al. (1986) fed a range of dicts to lactating cows at a frequency of either 2 or 24 meals daily. The effects on rumen fermentation were small but consistent. Rumen propionate concentrations declined whilst $(\mathrm{A}+\mathrm{B}) / \mathrm{P}$ ratios were elevated as meal frequency increased. Rumen $\mathrm{pH}$ remained stable but mean $\mathrm{pH}$ was gencrally 0.3-0.5 units lower for cows fed 24 times daily with one cow showing a difference of 0.9 units for a low roughage diet. However, the greatest effect of feeding frequency on $\mathrm{pH}$ occurs on high concentrate diets where the minimum daily $\mathrm{pH}$ is lower for a reduced number of meals (Sutton et al., 1986). A similar cffect was observed by Kaufmann et al. (1980) where cows were fed either 2 or 6 times daily. Twice daily feeding resulted in $\mathrm{pH}$ fluctuations between 5.85 and 6.65 whereas more frequent feeding produced a $\mathrm{pH}$ range of 6.15 to 6.4 . It is this minimum daily $\mathrm{pH}$ that is of critical importance in producing the differences observed for rumen starch digestibility. These effects are a consequence of change in the microbial population brought about by the variation in fermentable carbohydrate availability. Rapid fermentation of large single intakes of starch by bacteria such as Streptococcus bovis, lead to an accumulation of VFA and lactic acid within the rumen creating a drop in $\mathrm{pH}$ that halts the growth of the less acid tolerant microbes. Since protozoa can be particularly susceptible to acidic conditions, as feeding 
frequency declines so does the protozoal presence in the rumen (Moir and Somers, 1956; Froetschel et al., 1990). Bacterial populations as a whole are less affected by feeding frequency (Dehority and Orpin, 1997), although fibrolytic bacterial species are also highly susceptible to low minimum $\mathrm{pH}$ values in rumen fluid.

The blending of diet ingredients versus separate feeding of forage and concentrate fractions could influence starch digestion within the rumen. The activity of the microbes may be increased by the synchronisation of energy and protein availability. However, investigations into Total Mixed Rations (TMR) and more traditional systems of feeding have produced variable and inconclusive results (Villavicencio et al., 1968; Holter et al., 1977; Robinson and Sniffen, 1985; Yan et al., 1998). Determination of the influence on starch degradation is difficult due to the lack of information relating to the disappearance of starch rather than organic matter in general.

Leonard et al. (1989) investigated the effects of time of feeding maize grain to stecrs, relative to feeding the forage fraction of the diet. Total tract digestibility of starch did not differ for cows fed maize either with hay or after hay. However the mean retention time and rate of maize starch passage tended to be faster for steers fed whole maize grain after hay than those fed the maize at the same time as the hay.

Lynch et al. (1991) showed that injections of bovine somatotrophin (bST) to lactating dairy cows caused a shift in the digestion of starch towards the intestines and away from the rumen. However the $12 \%$ drop in ruminal starch degradability was not significant. Both dry matter and starch intakes did not differ between treatments suggesting that such effects of bST may warrant further investigation.

\section{Animal factors}

Even when diet and environment are similar, individual animals may demonstrate significantly different digestive responses. So called animal factors that might be involved are:

genotype

sex

milk yield

milk composition

stage of lactation

parity

pregnancy

disease state

parasite load

nutritional status

previous fecding

body condition. 
Age

Veerkamp and Emmans (1995) reviewed the impact of genetics as a source of variation in energetic efficiency of dairy cows. They concluded that high genetic merit cows are more efficient at milk production duc to differences in the partitioning of energy rather than through increases in digestive efficiency. Custodio et al. (1983) suggested that cows of different genetic merit did not differ in their ability to digest starch.

Booher et al. (1951) showed that the apparent digestibility of uncooked potato starch increased following prolonged feeding to young rats. In the ruminant, adaptation to a new diet can have a significant influence on starch digestibility due to the requirement for the microbial population to adjust to the new environment in the rumen created by the diet change. Cone (1991) showed that the percentage of starch degraded in vitro was significantly different between incubations based on rumen fluid from either a concentrate or hay fed cow. Hibberd et al. (1985) suggested that the influence of tannins on ruminal starch degradability was reduced or even eliminated where stecrs were adapted to sorghum based high tannin diets.

TOWARDS A DYNAMIC MECHANISTIC MODEL OF STARCH DIGESTION IN THE RUMEN OF THE LACTATING DAIRY COW - KEY PRINCIPLES

Several models of ruminant digestion have been proposed in the literature. Much of the emphasis in these models is placed on digestion within the rumen (Baldwin et al., 1977, 1987; France et al., 1982; Dijkstra et al., 1992; Baldwin, 1995; Lescoat and Sauvant, 1995). Duc to the differing objectives behind the various models described in the literature and the continual improvement in biological knowledge, starch digestion is represented in varying degrees of detail along with the digestion of other dietary carbohydrates. The purpose of this section is not to examine the specific mathematical description of these models, but to summarise the different approaches used to represent starch digestion in the dairy cow. Hence relevant schematic descriptions of starch digestion that are presented in the literature but not part of working models are also included in the following discussion.

\section{Dietary starch}

The representation of starch as an input to digestion varies widely between models. Danfacr (1990) includes starch along with organic acids, pectin, and lactate in a single fermentable sugars pool. Characterisation of the diet in this manner 
docs not allow the model to accurately account for starch relative to other fermentable sugars during rumen fermentation and passage to the lower digestive tract. Such an approach also removes the potential for constructing carbon and redox balances as well as detailing energetic expenditures or relationships (Baldwin, 1995). Quantifying starch intake as a specific dietary nutrient allows further description in terms of rumen degradation rates and potentially degradable fractions based on in situ and in vivo data. Such description has become more frequent within recent models of digestion, principally because of the importance of nutrient interactions within the rumen. These nutrient interactions can be described in more detail, as models become more complex in their representation of ingested nutrients (Beever et al., 1991).

So far this review has shown that the process of starch digestion in the dairy cow depends on many factors. Some of these factors should be clearly identified in the input to the model. Evidently the starch intake of a dairy cow has the potential to vary considerably depending on the diet formulated and appetite. Therefore any model attempting to simulate starch digestion must have the ability to represent large variations in total starch intake. Where possible, development of the model needs to be based on data from across the whole range of starch intakes. Where rumen models assume constant levels of intake (Russell et al., 1992; Sniffen et al., 1992) their application is limited to nearly ideal fecding practices. Incorporating pulsed intake functions (France et al., 1982) should provide an approach that can better simulate reality especially with regard to fluctuations in ruminal $\mathrm{pH}$ (Pitt and Pell, 1997).

The chemical and physical description of starch entering the model is clearly of utmost importance. The direct measurement of the degradation characteristics and particle size distribution of dictary starch may not be necessary as this review has shown that estimates should be possible provided that the starch source, degree of processing and passage rate information are available. This approach lends itself to practical application and avoids the expense and time consuming analysis of starchy feedstuffs. However, where accurate chemical description of the starch sources is available from standardised analyses, the output from a model will more closely resemble reality.

Beever (1993) presented a schematic diagram of starch digestion in the rumen in which starch entering the rumen was characterised as being potentially degradable or undegradable. The potentially degradable fraction was then split into starch actually degraded to hexose and that passing undegraded out of the rumen. This would allow for the description of starch sources such as sorghum and maize displaying proportions of the total starch that appear to be completely rumen undegradable due to starch-protein matrix associations. Although this review has shown that in situ studies suggest that only very small fractions of dietary starch fall into this category. Indeed, the determination of the truly undegradable starch fraction is 
complicated and time consuming as it requires an in situ or in vitro incubation of the starch for many hours, in conditions applicable to the situation under investigation. Black et al. (1981) described potentially rumen undegradable fractions of nutrients to be those remaining within the rumen after prolonged incubation. Dijkstra and France (1996) emphasise the importance of standardising any in vitro or in situ techniques used to describe data in the model. This will eliminate variation due to incubation times, mathematical expression and chemical treatments. The potentially rumen degradable starch will not be entirely digested within the rumen. A proportion will flow intact from the rumen (Table 4) and some may accumulate within the rumen depending on the relatjve rates of degradation and passage (Black et al., 1981).

Early mechanistic models of rumen digestion avoided description of feeds in terms of their physical attributes (Baldwin et al., 1977; Black et al., 1981; France et al., 1982). A more recent trend has been to describe the ingested nutrients in terms of their particle size distribution (Baldwin et al., 1987; Murphy and Kennedy, 1993; Baldwin, 1995). This accounts for differential degradation and passage rates of small and large particles, as well as soluble nutrients. This review along with the companion paper has shown how processing can dramatically influence degradation rates of starch not only in the rumen but also throughout the entire digestive tract. This is in part due to particle size characteristics. Therefore adequate representation of the distribution of starch between different particle sizes should facilitate a more accurate description of feedstuffs that have been processed differently. Lescoat and Sauvant (1995) distinguish between insoluble starch resulting from forage and from concentrate. This allows for both the different rates of digestion and passage between forage and concentrate derived starch.

Nocek and Tamminga (1991) described a framework for the digestion of carbohydrates in the rumen. Whilst the model describes the starch in terms of soluble, large, medium and small particle sizes, the starch entering the rumen is only catagorised as soluble or large particles. The degradation of these particles is then presented as resulting in the production of VFA. Passage rates for the different particle sizes depend on DMI. Table 4 showed that soluble starch is not necessarily completely degraded within the rumen. Therefore where models define a soluble starch fraction (Dijkstra et al., 1992) account nceds to be taken of its passage from the rumen as well as its degradation (Baldwin et al., 1987; Baldwin, 1995). This is especially true at the high intakes observed with today's dairy cows. The Dijkstra et al. (1992) model allowed the soluble starch to flow from the rumen with the fluid phase. In a set of simulations designed to evaluate this model in terms of its account of dictary starch (Dijkstra and France, 1995) soluble starch contributed between 1.1 and 18.7 percent of total starch outflow from the rumen, highlighting the significance of this process in certain dictary situations. 


\section{Microbial description}

The method used to represent the microbial population within the rumen varies widely between different models. The biological complexity of this area of ruminal fermentation has long been recognised. However, due to a lack of knowledge regarding the interrelationships between the different microbial species, models based around several different groups of microbial species have met with limited success. Simplified schemes involving single microbial pools (Baldwin et al., 1977; Black et al., 1981) are restricted, particularly with regard to describing digestion during dietary transition or the involvement of microbial interactions such as predation. A compromise between representing individual microbial specics and the entire microbial population as one pool is possible. Several researchers (Baldwin et al., 1987; Dijkstra et al., 1992) differentiate on the basis of substrate affinity between amylolytic and fibrolytic microbes. The characterisation of protozoa in these pools is subject to variation between models. Nocek and Tamminga (1991) do not represent the role of protozoa in starch digestion in their conceptualisation. Dijkstra et al. (1992) described their rumen model using three microbial groups contained within two pools. The pool of amylolytic microbes was split between protozoa and bacteria. However protozoal engulfment of bacteria was confined to that occurring between the protozoa and the fibrolytic bacteria. Therefore recycling of amylolytic bacteria was not adequately represented in this instance. With regard to starch digestion there are benefits to be gained via the description of protozoa in the rumen. This is due to the protozoal population's particular sensitivity to the concentration of starch in the diet and its ability to slow the rate of starch fermentation upon the appearance of starch in the rumen. Distinguishing between rumen protozoa and other amylotytic microbes also allows an improved description of starch and microbial polysaccharide escaping the rumen. This is of particular importance when the aim of the model is to represent digestive events throughout the digestive tract. Dijkstra (1994) presented a modified version of the rumen model previously described by Dijkstra et al. (1992). The aim of this modification was to more adequately simulate the dynamics of protozoa during digestion. In this modified model, three microbial groups (amylolytic bacteria, fibrolytic bacteria and protozoa) were distinguished. Dijkstra (1994) placed considerable emphasis on the representation of the engulfment of starch and amylolytic bacteria by protozoa. Substrate preference was described with protozoa being allowed to utilise both structural and non-structural carbohydrate sources. Amylolytic bacteria were confined to the utilisation of non-structural carbohydrate. The maintenance requirement of protozoa was assumed to remain constant unlike that for bacteria, which was dependent on nitrogen availability. The protozoal storage polysaccharide pool was itself used in a function to describe the inhibition of bacterial engulfment for conditions relating to high starch availability 
(Coleman, 1975). During evaluation of the model, Dijkstra (1994) showed that increasing dictary starch concentration decreased protozoal biomass on concentrate based diets in contrast to an increase for roughage based diets. This was a direct result of elevated protozoal lysis on the concentrate diet.

Baldwin et al. (1977) addressed the distribution of microbial matter within the rumen with a distinction between free microbes in the rumen fluid and microbes bound to particulate matter. This strategy allows for the description of different passage rates and different substrate affinities between these microbial groups. Dijkstra et al. (1992) assumed that the amylolytic bacteria live free in rumen fluid and that the outflow from the rumen reflected this assumption.

Empirical models of microbial growth (National Research Council, 1989) have assumed that the yield of microbial matter is a constant function of Total Digestible Nutrients (TDN) or organic matter digestion. This approach docs not involve substrate preference and it also fails to account for microbial maintenance energy requirements. Both Baldwin et al. (1977) and Black ct al. (1981) described microbial growth as a function of $Y_{\text {ATP }}$ (yield of microbial cells / mole ATP) and importantly they also included a microbial maintenance requirement. These are concepts that have been retained in many more recent models (France et al., 1982; Baldwin et al., 1987; Dijkstra et al., 1992; Russell et al., 1992) although accounting for the differences in $Y_{\text {AIP }}$ between microbial species is difficult (Russell and Strobel, 1993). The chemical composition of microbial DM has been described in various levels of detail. Many models assume a constant chemical composition (Baldwin et al., 1977, 1987; France et al., 1982). However, Dijkstra et al. (1992) and Dijkstra (1994) allowed polysaccharide content of the amylolytic microbes to alter depending on the availability of nonstructural carbohydrate in relation to nitrogen availability. Such an approach is also advocated by AFRC (1999). This is undoubtedly an important element in the prediction of the fate of hexose within the rumen and the supply of microbial biomass to the small intestine.

\section{Starch degradation by the microbial population}

The expressions used to represent enzyme kinetics within the rumen are generally mass action or Michaelis Menten in nature. Where parameterisation of Michaclis Menten equations is possible, these equations provide a better description of reality than that obtained with mass action kinetics (Baldwin, 1995). Based on the assumption that the microbial mass behaves like an enzyme, the Michaclis-Menten model assumes that the microbial mass can limit digestion (Mertens, 1993). This is in contrast with mass action kinetics where only the intrinsic properties of the substrate are considered.

In the scheme presented by Nocek and Tamminga (1991) hexose does not appear as a pool, and this simplification does not allow for the accurate description 
of the different fates of hexose within the rumen. The availability of a hexose pool would be particularly important when predicting the proportions utilised in microbial growth, VFA production, and ATP production. AFRC (1999) show how a hexose pool also provides a convenient point at which the degradation of other hexose containing substrates such as sugars, pectin, cellulose, or hemicellulose can be incorporated into any model of ruminant digestion.

The rate of starch degradation can be given in the input to the model (Russell et al., 1992; Sniffen et al., 1992) and it can be allowed to vary depending on the size and activity of the amylolytic microbial pool. Where the microbial pool influences degradation, factors such as nitrogen availability, and $\mathrm{pH}$ can indirectly influence the degradation of starch. Accounting for reduced microbial activity at low $\mathrm{pH}$ has implications for structural carbohydrate digestion as well as starch degradation. Pitt and Pell (1997) discussed ruminal $\mathrm{pH}$ fluctuation with particular emphasis on meal frequency and substrate digestion rates. The need for a separate lactate pool was highlighted since lactate has a much lower dissociation constant $\left(\mathrm{pK}_{\mathrm{d}}\right)$ than the VFA and it is also metabolised by the microbes. Dijkstra (1994) accounts for the influence of $\mathrm{pH}$ in terms of the length of time rumen $\mathrm{pH}$ is below a critical point affecting fibre degradation and mean $\mathrm{pH}$, both of which are inputs to the model based on experimental observations. Therefore this model does not have the ability to predict $\mathrm{pH}$ fluctuations from the dietary inputs and rumen fermentation processes.

\section{Model evaluation}

When evaluating models of digestion in order to test adequacy of prediction, it is important to consider the objectives upon which the models are based (Dijkstra and France, 1996). Arguably, the model most suited to simulating the digestion of different starch sources in the rumen is that of Dijkstra (1994). Here the objective of representing protozoal dynamics within a whole rumen function model is particularly relevant to starch utilisation in the rumen. When the model of Dijkstra et al. (1992) was used to simulate the digestion of starch in the rumen, a good relationship existed between observed and predicted levels of starch outflow from the rumen (Dijkstra and France, 1995, 1996). The experiments used to test the model represented a wide range of DMI (4-25 kg day-1) along with starch contents varying from $10-550 \mathrm{~g} / \mathrm{kg}$ DM. In an independent evaluation of the rumen models of Baldwin et al. (1987), Danfacr (1990) and Dijkstra et al. (1992), Bannink et al. (1997) reported a rather high prediction error of the models from 60 to 150 percent. On a high starch diet, the Dijkstra ct al. (1992) model was most accurate, whilst on low starch diets the Danfaer (1990) model performed the best. With regard to rumen fermentation in general, the prediction of VFA production within the rumen has been unreliable (Baldwin et al., 1987). Indeed, on high starch diets 
the prediction of nutrient digestion was also less satisfactory than on diets of lower concentrate inclusion. Beever (1993) suggests that this is, at least in part, due to the lack of an adequate description of the effects of low $\mathrm{pH}$ on fibrolytic microbial activity. Taking account of reduced microbial fermentation at low ruminal $\mathrm{pH}$ levels might avoid the over-prediction of VFA production as seen by Baldwin et al. (1987). Since high starch dicts are often associated with low rumen $\mathrm{pH}$, the ability of a model to simulate the consequences on microbial activity is likely to be central to its success. Rumen $\mathrm{pH}$ can also influence the rate of individual VFA absorption, since only undissociated VFA can diffuse across the rumen epithelium (Gäbel and Martens, 1991). Indeed Dijkstra (1994) does account for this effect of $\mathrm{pH}$ although $\mathrm{pH}$ itself is a driving variable. Bannink et al. (1997) confirmed that none of the three models under evaluation were able to accurately predict molar VFA proportions. Dijkstra (1994) suggested that future attempts to predict rumen VFA production and absorption should involve the effect of VFA chainlength on absorption rates and the different VFA production profiles observed between protozoa and bacteria.

Ewing and Johnson (1987) found initial simulations of their model to be unacceptable with regard to predicted starch digestibilities through the digestive tract. Digestion rates were subsequently altered to allow prediction of data from Turgeon et al. (1983). The degree of alteration needed highlighted the inadequacy of the original model in several areas. Initial predictions of ruminal digestibilities were far too low, as was total tract starch digestion. This underestimation was accounted for by the inability of in vitro and in situ data used to build the model and predict in vivo starch digestion rates. Subsequent to parameter re-estimation the relationship between predicted and observed values of total tract digestion was poor $(\mathrm{R}=0.237)$.

\section{A CONCEPTUAL FRAMEWORK FOR A MECHANISTIC MODEL OF STARCH DIGESTION IN THE LACTATING DAIRY COW}

\section{Objective}

This review has described some of the important nutritional interactions that can take place in the rumen in terms of nitrogen and starch supply and even other forms of fermentable carbohydrate. Therefore, from a modelling perspective, starch digestion in the rumen cannot be isolated from these other feed components. Unless vastly simplifying assumptions are to be made, such as an non-limiting nitrogen supply as a substrate for the microbes on all diets or ignoring the effect of increased levels of dietary fibre on passage rate and fermentation patterns, certain essential non-starch aspects of digestion must be accounted for. Existing models 
of whole rumen function do take account of all major diet components. Therefore Figure 9 shows the biological basis for a mechanistic model of starch digestion in the rumen based around the principle that the scheme forms a component of an existing whole rumen model such as that developed by Dijkstra (1994). This approach has advantages over the development of an entirely new model as it is quicker and the success of the exercise can be evaluated in terms of the model performance before and after modification. The objective of this model is to predict the degree of starch digestion and define the end products of digestion as they occur for different quantities and sources of dictary starch alongside prediction of their disappearance from the rumen. Therefore it is concerned with the disappearance of starch in terms of rumen outflow and degradation and not the appearance of the products of digestion in the portal blood supply.

\section{Rumen description}

Using the relevant in situ, in vivo and in vitro data, a given quantity of starch entering the model needs to be characterised in terms of the following:

1. Degradability of the starch in the rumen, small intestine and large intestine

2. Physical form of starch; proportions of large, small and soluble fractions.

The digestion of starch depends on the pools of starch and microorganisms present in the system. The model describes the differential passage through the digestive tract of large and small particles of the starch pool. Soluble starch is also defined in the rumen. Further subdivision of particle sizes may be justifiable on biological grounds in order to represent the effect of differential passage rates and the influence of surface area to starch ratio on amylolytic activity. However, a balance needs to be struck between biological detail and the need to keep the first run of the model as simple as possible to aid evaluation and understanding. As each of these fractions is degraded, the resulting hexose becomes available to the amylolytic rumen microbes. Starch digestion to glucose is not separated into products of amylase and oligosaccharidase activity in the rumen. The intermediary products of enzymatic degradation such as limit dextrins, maltose and isomaltose, remain as a component of the starch pool until completely degraded to glucose. The microbial population consists of two separate pools of amylolytic bacteria and amylolytic protozoa. The amylolytic microbes and the protozoa are not defined in terms of the dynamics of specific species. Therefore fractional rates of microbial growth or uptake of starch and engulfment of small bacteria by protozoa are based on those observed for a previously determined microbial population structure. However, both substrate availability and $\mathrm{pH}$ will affect these rates. Amylolytic bacteria are further described as those that are free within the rumen fluid and 


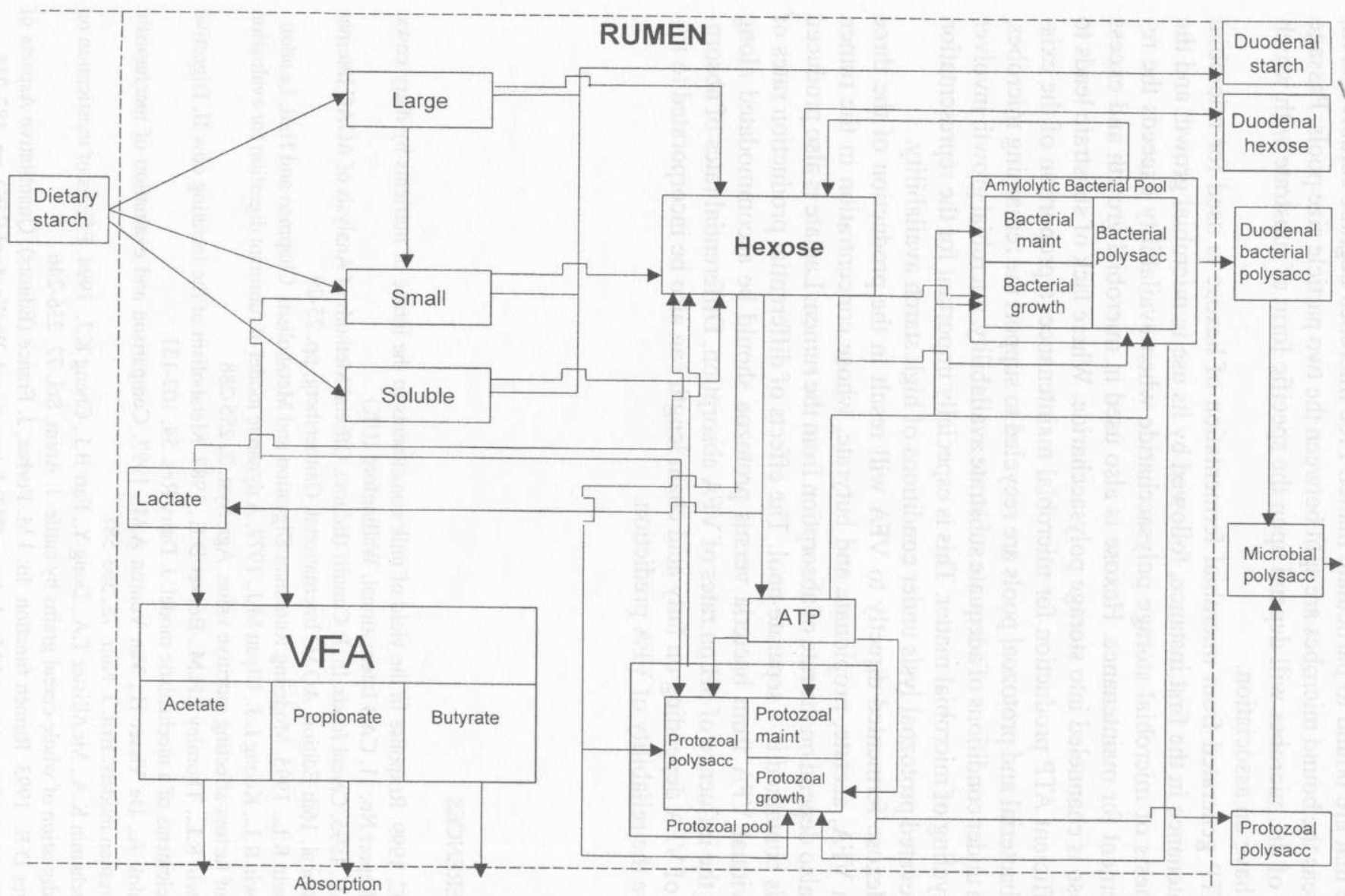

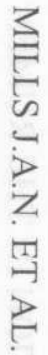

Figure 9. A conceptual framework for a mechanistic model of starch digestion in the rumen of the lactating dairy cow 
those that are bound to particulate matter. Free microbes degrade soluble starch, whereas the bound microbes are split between the two particle size pools. Passage rates of the microbes will depend upon the specific form of substrate with which they have an association.

ATP generated from microbial fermentation of hexose is used for microbial maintenance in the first instance, followed by its use in microbial growth and the synthesis of microbial storage polysaccharide when availability exceeds the requirement for maintenance. Hexose is also used in microbial growth and excess hexose is channeled into storage polysaccharide. Where lack of substrate leads to insufficient ATP production for microbial maintenance, a proportion of the existing bacterial and protozoal pools are recycled to support the remaining microbes. Even under conditions of adequate substrate availability, microbial growth involves a recycling of microbial matter. This is especially important for the representation of elevated protozoal lysis under conditions of high starch availability.

Hexose fermented directly to VFA will result in the production of the three main VFA, acetate, propionate and butyrate, whose concentration in the rumen will also depend on the rate of absorption from the rumen. Lactate is also produced and is contained in a separate pool. The effects of differential production rates of individual VFA from bacteria versus protozoa should be accommodated along with the influence of $\mathrm{pH}$ on rates of VFA absorption. Differential rates of absorption of VFA depending on fatty acid chain length can also be incorporated to improve the reliability of VFA prediction.

\section{REFERENCES}

AFRC, 1999. Response in the yield of milk constituents to the intake of nutrients by dairy cows. Report No. 11. CAB Intemational, Wallingford (UK)

AOAC, 1995. Cereal foods. In: P. Cunniff (Editor). Official Methods of Analysis of AOAC International. 16th Edition. AOAC International, Gaithersherg. pp. 25-29

Baldwin R.L., 1995. Modeling Ruminant Digcstion and Metabolism. Chapman and Hall, London

Baldwin R.L., Koong L.J.. Ulyatl M.J., 1977. A dynamic model of ruminant digestion for cvaluation of factors affecting nutritive value. Agr. Syst. 2, 255-288

Baldwin R.L., Thornley J.H.M., Beever D.E.. 1987. Metabolism of the lactating cow II. Digestive clements of a mechanistic model. J. Dairy Res. 54, 107-131

Bannink A.. De Visser H., Van Vuuren A.M., 1997. Comparison and cvaluation of mechanistic rumen models. Brit. J. Nutr. 78, 563-581

Beauchemin K.A., McAllister T.A., Dong Y., Farr B.I., Cheng K.J., 1994. Effects of mastication on digestion of whole cereal grains by cattle. J. Anim. Sci. 72, 236-246

Beever D.E., 1993. Rumen function. In: J.M. Forbes, J. France (Editors). Quantitative Aspects of Ruminant Digestion and Metabolism. CAB International, Wallingford (UK), pp. 187-215 
Beever D.E., 1999. Functionality of Feeds. DRC Dairylink Jan/Feb, 8-10

Beever D.E., Cammell S.B., Humphries D.J., 1996. The effect of stage of maturity at the time of harvest on the subsequent nutritive value of maize silage fed to lactating cows. Cedar Report 66

Beever D.E., Rook A.J., France J., Dhanoa M.S., Gill M., 1991. A review of empirical and mechanistic models of lactational performance by the dairy cow. Livest. Prod. Sci. 29, 115-130

Black J.L., Beever D.E., Faichney G.J., Howarth B.R., Graham N.M., 1981. Simulation of the effects of rumen function on the flow of nutrients from the stomach of sheep: part 1-description of a computer program. Agr. Syst. 6, 195-219

Booher L.E., Behan I., McMeans E., 1951. Biologic utilization of unmodified and modified food starches. J. Nutr. 45, 75-95

Brunt K., Sanders P., Rozema T., 1998. The enzymatic determination of starch in food, feed and raw materials of the starch industry. Stärke 50, 413-419

Cameron M.R., Klusmeyer T.H., Lynch G.L., Clark J.H., Nelson D.R., 1991. Effects of urea and starch on rumen fermentation, nutrient passage to the duodenum, and performance of cows. J. Dairy Sci. 74, 1321-1336

Chalupa W., 1977. Manipulating rumen fermentation. J. Anim. Sci. 45, 585-599

Chamberlain D.G., Robertson S.,.Choung J.J., 1993. Sugars versus starch as supplements to grass silage: Effects on ruminal fermentation and the supply of microbial protein to the small intestine, estimated from the urinary excretion of purine derivatives, in sheep. J. Sci. Food Agr. 63, 189-194

Chen K.H., Huber J.T., Theurer C.B., Swingle R.S., Simas J., Chan S.C., Wu Z., Sullivan J.L., 1994. Effect of steam flaking of corn and sorghum grains on performance of lactating cows. J. Dairy Sci. 77, 1038-1043

Coleman G.S., 1975. The interrelationship between rumen ciliate protozoa and bacteria. In: I.W. McDonald, A.C.I. Warner (Editors). Digestion and Metabolism in the Ruminant. University of New England Publishing Unit, pp. 149-164

Coleman G.S., 1986. The amylase activity of 14 species of entodiniomorphid protozoa and the distribution of amylase in rumen digesta fractions of sheep containing no protozoa or one of seven different protozoal populations. J. Agr. Sci. 107, 709-721

Coleman G.S., 1992. The rate of uptake and metabolism of starch grains and cellulose particles by Entodinium species, Eudiplodinium maggii, some other entodiniomorphid protozoa and natural protozoa populations taken from the ovine rumen. J. Appl. Bacteriol. 73, 507-513

Cone J.W., 1991. Degradation of starch in feed concentrates by enzymes, rumen fluid and rumen enzymes. J. Sci. Food Agr. 54, 23-34

Cone J.W., Tas A.C., Wolters M.G.E., 1992. Pyrolysis mass spectrometry (PyMS) and degradability of starch granules. Stärke 44, 55-58

Cone J.W., Vlot M., 1990. Comparison of degradability of starch in concentrates by enzymes and rumen fluid. J. Anim. Physiol. Anim. Nutr. 63, 142-148

Cotta M.A., 1992. Interactions of ruminal bacteria in the production and utilisation of maltooligosaccharides from starch. Appl. Environ. Microbiol. 58, 48-54

Custodio A.A., Blake R.W., Dahm P.F., Cartwight T.C., Scelling G.T., Coppock C.E., 1983. Relationships between measures of feed efficiency and transmitting ability for milk of Holstein cows. J. Dairy Sci. 66, 1937-1946

Czerkawski J.W., 1976. The chemical composition of microbial matter in the rumen. J. Sci. Food Agr. 27, 621-632

Danfaer A., 1990. A dynamic model of nutrient digestion and metabolism in lactating dairy cows. $\mathrm{Ph}$. D. Thesis. Report from the National Institute of Animal Science, Denmark 
De Visser H., 1993. Characterisation of carbohydrates in compound leeds. In: P.C. Garnsworthy, D.J.A. Cole (Editors). Recent Advances in Animal Nutrition. Nottingham University Press, Nottingham, pp. 19-38

De Visser H., Klop A., Van der Meulen J, Van Vuuren A.M., 1998. Influence of maturity of grass silage and flaked corn starch on the production and metabolism of volatile fatty acids in dairy cows. J. Dairy Sci. 81, 1028-1035

Dehority B.A., Orpin C.G., 1997. Development of, and natural tluctuations in, rumen microbial populations. In: P.N. Hobson, C.S. Stewart (Editors). The Rumen Microbial Ecosystem, 2nd Edition. Blackic Academic and Professional, London, pp. 196-245

DesBordes C.K., Welch J.G., 1984. Influence of specific gravity on rumination and passage of indigestible particles. J. Anim. Sci. 59, 470-475

Dijkstra J., 1994. Production and absorption of volatile fatty acids in the rumen. Livest. Prod. Sci. $39,61-69$

Dijkstra J., 1994. Simulation of the dynamics of protozoa in the rumen. Brit. J. Nutr. 72, 679-699

Dijkstra J.. France J., 1995. Mathematical integration of starch degradation and outflow in the rumen. Abstacts of the SCI Symposium on Carbohydrates in Feeds for Ruminants

Dijkstra J., France J., 1996. A comparative evaluation of models of whole rumen function. Ann. Zootech. 45, 175-192

Dijkstra J., France J., 1996. Starch in ruminant diets: A modelling approach. Paper presented at the Maize Growers Association Conference, Royal Agricultural College, Cirencester

Dijkstra J., Neal H.D.St.C., Beever D.E., France J., 1992. Simulation of nutrient digestion, absorption and outllow in the rumen: model description. J. Nutr. 122, 2239-2256

Eadie J.M., Mann S.O., 1970. Development of the rumen microbial population: High starch diets and instability. In: A.T. Phillipson (Editor). Physiology of Digestion and Metabolism in the Ruminant. Proceedings of the 3rd International Symposium. Oriel Press Ltd., pp. 335-347

Erdman R.A., 1988. Dietary buffering requirements of the lactating dairy cow: A review. J. Dairy Sci. $71,3246-3266$

Espindola M.S., DePeters E.J., Fadel J.G., Zinn R.A., Perez-Monti H., 1997. Effects on nutrient digestion of wheat processing and method of tallow addition to the diets of lactating dairy cows. J. Dairy Sci. 80, $1160-1171$

Ewing D.L., Johnson D.E., 1987. Corn particle starch digestion, passage and size reduction in beef steers: a dynamic model. J. Anim. Sci. 64, 1194-1204

Ewing D.L., Johnson, D.E.. Rumpler W.V., 1986. Corn particle passage and size reduction in the rumen of beef steers. J. Anim. Sci. 63, 1509-1515

Feng P., Hunt C.W., Pritchard, G.T., Parish S.M., 1995. Effect of barley variety and dietary barley content on digestive function in becf steers fed grass hay-based diets. J. Anim. Sci. 73, 3476-3484

Fluharty F.L., Loerch S.C., 1989. Chemical treatment of ground corn to limit ruminal starch digestion. Can. J. Anim. Sci. 69, 173-180

Forbes J.M., France J., 1993. Introduction. In: J.M. Forbes, J. France (Editors). Quantitative Aspects of Ruminant Digestion and Metabolism, CAB International, Wallingford (UK), pp. 1 -10

France J., Dijkstra J., Dhanoa M.S., Baldwin R.L., 1998. Biomathematical applications in ruminant nutrition. J. Franklin Inst. 335B, 241-258

France J., Thornley J.H.M., 1984. Mathematical Models in Agriculture. Butterworths, London

France J., Thornley J.H.M., Beever D.E., 1982. A mathematical model of the rumen. J. Agr. Sci. 99, 343-353

Froetschel M.A., Martin A.C.. Amos H.E., Evans J.J., 1990. Effects of zinc sulfate concentration and feeding frequency on ruminal protozoal numbers, fermentation patterns and amino acid passage in stcers. J. Anim. Sci. 68, 2874-2884 
Galyean M.L., Wagner D.G., Owens F.N., 1981. Dry matter and starch dissappearance of corn and sorghum as influenced by particle size and processing. J. Dairy Sci. 64, 1804-1812

Gäbel G., Martens H., 1991. Transport of $\mathrm{Na}^{+}$and $\mathrm{Cl}^{-}$across the forestomach epithelium: Mechanisms and interactions with short-chain fatty acids. In: T. Tsuda, Y. Sasaki, R. Kawashima (Editors). Physiological Aspects of Digestion and Metabolism in Ruminants. Academic Press Inc., San Diego, pp. 129-151

Genthner S.B.R., Davis C.L., Bryant M.P., 1981. Features of rumen and sewage sludge strains of Eubacterium limosum, a methyl-utilizing and hydrogen-carbon dioxide-utilizing species. Appl. Environ. Microbiol. 42, 12-19

Hahn D.H., Rooney L.W., Earp C.F., 1984. Tannins and phenols of sorghum. Cereals Food World $29,776-779$

Hale W.H., 1973. Influence of processing on the utilization of grains (starch) by ruminants. J. Anim. Sci. 37, 1075-1080

Herrera-Saldana R.E., Gomez-Alarcon R., Torabi M., Huber J.T., 1990a. Influence of synchronizing protein and starch degradation in the rumen on nutrient utilization and microbial protein synthesis. J. Dairy Sci. 73, 142-148

Herrera-Saldana R.E., Huber J.T., 1989. Influence of varying protein and starch degradabilities on performance of lactating cows. J. Dairy Sci. 72, 1477-1483

Herrera-Saldana R.E., Huber J.T., Poore M.H., 1990b. Dry matter, crude protein, and starch degradability of five cereal grains. J. Dairy Sci. 73, 2386-2393

Hespell R.B., Bryant M.P., 1979. Efficiency of rumen microbial growth: Influence of some theoretical and experimental factors on $\mathrm{Y}_{\text {ATP. }}$. Anim. Sci. 49, 1640-1659

Hibberd C.A., Wagner D.G., Hintz R.L., Griffin D.D., 1985. Effect of sorghum grain variety and reconstitution on site and extent of starch and protein digestion in steers. J. Anim. Sci. 61, $702-712$

Holter J.B., Urban W.E., Hayes H.H., Davis H.A., 1977. Utilisation of diet components fed blended or separately to lactating dairy cows. J. Dairy Sci. 60, 1288-1293

Huntington G.B., 1997. Starch utilization by ruminants: From basics to the bunk. J. Anim. Sci. 75, $852-867$

Joy M.T., DePeters E.J., Fadel J.G., Zinn R.A., 1997. Effects of corn processing on the site and extent of digestion in lactating cows. J. Dairy Sci. 80, 2087-2097

Kaufmann W., Hagemeister H., Dirksen G., 1980. Adaptation to changes in dietary composition level and frequency of feeding. In: Y. Ruckebusch, P. Thivend (Editors). Digestive Physiology and Metabolism in Ruminants. MTP Press, Lancaster, pp. 587-602

Kennedy P.M., Poppi D.P., 1984. 'Critical particle size' in sheep and cattle. In: P.M. Kennedy (Editor). Techniques in Particle Size Analysis of Feed and Digesta in Ruminants. Occasional Publication No.1. Canadian Society of Animal Science, pp. 170

Kent N.L., Evers A.D., 1994. Kent's Technology of Cereals. 4th Edition. Pergamon Press, Oxford

Klusmeyer T.H., Lynch G.L., Clark J.H., Nelson D.R., 1991a. Effects of calcium salts of fatty acids and proportion of forage in diet on ruminal fermentation and nutrient flow to duodenum of cows. J. Dairy Sci. 74, 2220-2232

Klusmeyer T.H., Lynch G.L., Clark J.H., Nelson D.R., 1991b. Effects of calcium salts of fatty acids and protein source on ruminal fermentation and nutrient flow to duodenum of cows. J. Dairy Sci. 74, 2206-2219

Klusmeyer T.H., McCarthy R.D., Clark J.H., Nelson D.R., 1990. Effects of source and amount of protein on ruminal fermentation and passage of nutrients to the small intestine of lactating cows. J. Dairy Sci. 73, 3526-3537 
Knowlton K.F., Allen M.S., Erickson P.S., 1996. Lasalocid and particle size of corn grain for dairy cows in early lactation. 2. Effect on ruminal measurements and feeding behavior. J. Dairy Sci. $79,565-574$

Knowlion K.F., Glenn B.P., Erdman R.A.. 1998. Performance ruminal fermentation and site of starch digestion in early lactation cows fed corn grain harvested and processed differently. J. Dairy Sci. 81, 1972-1984

Kotarski S.F., Waniska R.D., Thurn K.K., 1992. Starch hydrolysis by the ruminal microtlora. J. Nutr. 122, 178-190

Krause M., Beauchemin K.A., Rode L.M., Farr B.I., Norgaard P., 1998. Fibrolytic enzyme treatment of barley grain and source of forage in high grain diets fed to growing cattle. J. Anim. Sci. 76, 29!2-2920

Kreikemeier K.K., Harmon D.L., Brandt R.T., Nagaraja T.G., Cochran R.C., 1990. Steam rolled wheat diets for tinishing cattle: Effects of dietary roughage and feed intake on linishing steer performance and ruminal metabolism. J. Anim. Sci. 68, 2130-2141

Kung L., Tung R.S., Slyter L.L., 1992. In vitro effects of the ionophore lysocellin on ruminal fermentation and microbial populations. J. Anim. Sci. 70, 281-288

Leonard E.S., Pond K.R., Harvey R.W., Crickenberger R.G.. 1989. Effects of corn grinding and time of corn feeding on growth starch utilization and digesta passage characteristics of growing steers fed hay-based diets. J. Anim. Sci. 67, 1603-1611

Lescoat P., Sauvant D., 1995. Development of a mechanistic model for rumen digestion validated using the duodenal flux of amino acids. Reprod. Nutr. Develop. 35, 45-70

Lynch G.L., Klusmeyer T.H., Cameron M.R., Clark J.H., Nelson D.R., 1991. Effects of somatotrophin and duodenal infusion of amino acids on nutrient passage to duodenum and performance of dairy cows. J. Dairy Sci. 74, 3117-3127

Mackic R.I., Gilchrist F.M.C., 1978. Microbiological and chemical changes in the rumen during the stepwise adaptation of shecp to high concentrate diets. J. Agr. Sci. 90, 241-254

Mackae J.C., Armstrong D.G., 1968. Enzyme method for determination of $\alpha$-linked glucose polymers in biological materials. J. Sci. Food Agr. 19, 578-581

MacRac J.C., Buttery P.J., Beever D.E., 1988. Nutrient interactions in the dairy cow. In: P.C. Garnsworthy (Editor). Nutrition and Lactation in the Dairy Cow. Butterworths, London, pp. 55-75

Mayne C.S., Doherty J.G., 1996. The effect of fine grinding or sodium hydroxide treatment of wheat offered as part of a concentrate supplement on the perfornance of lactating dairy cows. Anim. Sci. 63, 11-19

McAllister T.A., Rode L.M., Cheng K.J., Buchanan-Smith J.G., 1992. Etfect of formaldehyde-treated barley or escape protein on the ruminal environment and digestion in steers. Can. J. Anim. Sci. $72,317-328$

McCarthy R.D., Klusmeyer T.H., Vicini J.L., Clark J.H., Nelson D.R., 1989. Effects of source of protein and carbohydrate on ruminal fermentation and passage of nutrients to the small intestine of lactating cows. J. Dairy Sci. 72, 2002-2016

Mcdonald P.. Edwards R.A., Greenhalgh J.F.D., Morgan C.A., 1995. Animal Nutrition. 5th Edition. Longman Scientific and Technical, Harlow

McWethy S.J., Hartman P.A., 1977. Purification and some properties of an extracellular $\alpha$-amylase from Bacteroides amylophilus. J. Bacteriol. 129, 1537-1544

Mendoza G.D., Britton R.A., Stock R.A., 1993. Influence of ruminal protozoa on site and extent of starch digestion and ruminal fermentation. J. Anim. Sci. 71, 1572-1578

Mertens D.R., 1993. Rate and extent of digestion. In: J.M. Forbes, J. France (Editors). Quantitative Aspects of Ruminant Digestion and Metabolism. CAB International Wallingford (UK), pp. $13-51$ 
Miron J, Ben-Ghedalia D., Solomon R., 1997. Digestibility by dairy cows of monosaccharide components in diets containing either ground sorghum or sorghum grain treated with sodium hydroxide. J. Dairy Sci. 80, 144-151

Moir R.J. Somers M., 1956. A factor influencing the protozoal population in sheep. Nature 178, 1472

Morgan D.J.. Cody R.F., Upton P.K., 1989. Cereal digestion in the ruminant. Irish. J. Agr. Res. 28, 43-48

Murphy M.R., Kennedy P.M., 1993. Particle dynamics . In: J.M. Forbes, J. France (Editors). Quantitative Aspects of Ruminant Digestion and Metabolism. CAB International, Wallingford (UK), pp. 87-105

National Research Council (NRC), 1989. Nutrient Requirements of Domestic Animals. Nutricnt Requirements of Dairy Cattlc. 6th Edition. National Academy of Sciences Press, Washington, DC

Nocek J.E., Tamminga S., 1991. Site of digestion of starch in the gastrointestinal tract of dairy cows and its effect on milk yield and composition. J. Dairy Sci. 74, 3598-3629

Olivera J.S., Huber J.T., Ben-Ghedalia D., Swingle R.S., Theurer C.B., Pessarakli M., 1993. Influence of sorghum grain on performance of lactating cows. J. Dairy Sci. 76, 575 - 585

Overton T.R., Cameron M.R., Elliot1 J.P., Clark J.H., Nelson D.R., 1995. Ruminal fermentation and passage of nutrients to the duodenum of lactating cows fed mixtures of corn and barley. J. Dairy Sci. 78, 1981-1998

Owens F.N., Zinn R.A., Kim Y.K., 1986. Limits to starch digestion in the ruminant small intestine. J. Anim. Sci. 63, 1634-1648

Orskov E.R., 1976. The effect of processing on digestion and utilization of cereals by ruminants. Proc. Nutr. Soc. 35, 245-252

Ørskov E.R., 1986. Starch digestion and utilization in ruminants. J. Anim. Sci. 63, 1624-1633

Palmquist D.L.. Weisbjerg M.R.. Hvelplund T., 1993. Ruminal intestinal and total tract digestibilities of nutrients in cows led diets high in fat and undegradable protein. J. Dairy Sci. 76, 1353-1364

Philippeau C., Le Deschault de Mondredon F., Michalet-Doreau B., 1999. Relationship between numinal starch degradation and the physical characteristics of corn grain. J. Anim. Sci. 77, 238-243

Philippeau C., Michalet-Doreau B., 1997. Influence of genotype and stage of maturity of maize on rate of ruminal starch degradation. Anim. Feed Sci. Tech. 68, 25-35

Philippeau C., Michalet-Doreau B., 1998. Intluence of genotype and ensiling of corn grain on in situ degradation of starch in the rumen. J. Dairy Sci. 81, 2178-2184

Pitt R.E., Pell A.N., 1997. Modeling ruminal pH fluctuations: Interactions betwecn meal frequency and digestion rate. J. Dairy Sci. 80, 2429-2441

Plascencia A., Zinn R.A., 1996. In1luence of llake density on the feeding value of steam-processed corn in dicts for lactating cows. J. Anim. Sci. 74, 310-316

Pomeranz Y.. 1984. Functional Properties of Food Components. Academic Press

Pond K.R., Tolley E.A., Ellis W.C., Matis J.H., 1984. A method for describing the weight distribution of particles from sieved lorage. In: P.M. Kennedy (Editor). Techniques in Particle Size Analysis of Feed and Digesta in Ruminants. Occasional Publication No.1. Canadian Socicty of Animal Science, pp. 123-133

Poore M.H., Moore J.A., Eck T.P., Swingle R.S., Theurer C.B., 1993a. Effect of fiber source and ruminal starch degradability on site and extent of digestion in dairy cows. J. Dairy Sci. 76, 2244-2253

Poore M.H., Moore J.A., Swingle R.S., Eck T.P., Brown W.H., 1993b. Response of lactating Holstein cows to diets varying in fiber source and ruminat starch degradability. J. Dairy Sci. 76. 2235-224.3 
Preston R.L., Brake A.C., Karnezos T.P., Matches A.G., Xiong Y., 1993. Near infrared reflectance and gelatinisation as measures of starch availability in steam flaked sorghum grain. Texas Tech. Univ. Agr. Sci. Tech. T-5-327, p. 189

Reynolds C.K.. Sutton J.D., Beever D.E. 1997. Effects of feeding starch to dairy cattle on nutrient availability and production. In: P.C. Garnsworthy, J. Wiseman, W. Haresign (Editors). Recent Advances in Animal Nutrition. Nottingham University Press, Nottingham, pp. 105-133

Robinson P.H., Sniften C.J., 1985. Forestomach and whole tract digestibility for lactating dairy cows as influenced by feeding frequency. J. Dairy Sci. 68, 857-867

Rooney L.W., Pflugfelder R.L., 1986. Factors affecting starch digestibility with special emphasis on sorghum and corn. J. Anim. Sci. 63, 1607-1623

Russell J.B., Chow J.M., 1993. Another theory for the action of ruminal buffer salts: Decreased starch fermentation and propionate production. J. Dairy Sci. 76, 826-830

Russell J.B., O'Connor J.D., Fox D.G., Van Soest P.J., Sniffen C.J., 1992. A net carbohydrate and protein system for evaluating cattle diets: I. Ruminal lermentation. J. Anim. Sci. 70, $3551-3561$

Russell J.B., Strobel H.J., 1993. Microbial energetics. In: J.M. Forbes, J. France (Editors). Quantitative Aspects of Ruminant Digestion and Metabolism. CAB International, Wallingford (UK), pp. $165-186$

Santos F.A.P., Huber J.T.. Theurer C.B., Swingle R.S., Wu Z., Simas J., Chen K.H., Chan S.C., Santos J., DePeters E.J., 1997. Comparison of barley and sorghum grain processed at different densities for lactating dairy cows. J. Dairy Sci. 80, 2098-2103

Schroeder J.W., Marx G.D., Park C.S., 1998. Waxy corn as a replacement for dent corn for lactating dairy cows. Anim. Feed Sci. Tech. 72, 111-120

Simas J., Huber J.T.. Theurer C.B., Chen K.H., Santos F.A.P., Wu Z., 1997. Influence of fat source and sorghum grain treatment on performance and digestibilities of high yielding dairy cows.

J. Dairy Sci. 80, 2907-2912

Slyter L.L.. Oltjen R.R., Kern D.L., Blank F.C.. 1970. Influence of type and level of grain and diethylstilbestrol on the rumen microbial populations of steers fed all-concentrate diets. I. Anim. Sci. 31, 996-1002

Smith L.W., Weinland B.T., Waldo D.R., Leffel E.C. 1983. Rate of plant cell wall particle size reduction in the rumen. J. Dairy Sci, 66, 2124-2136

Sniften C.J., O'Connor J.D., Van Soest P.J., Fox D.G., Russell J.B., 1992. A net carbohydrate and protein system for evaluating cattle diets: II. Carbohydrate and protein availability. J. Anim. Sci. 70, 3562-3577

Snow P., O'Dea K., 1981. Factors affecting the rate of hydrolysis of starch in food. Amer. J. Clin. Nutr. 34, 2721-2727

Streeter M.N., Wagner D.G., Hibberd C.A., Mitchell E.D., Oltjen J.W., 1990. Effect of variety of sorghum grain on digestion and availability of dry matter and starch in vitro. Anim. Feed Sci. Tech. 29, 279-287

Sutton J.D., 1985. Digestion and absorption of energy substrates in the lactating cow. J. Dairy Sci. $68,3376-3393$

Sutton J.D., Hart I.C. Broster W.H., Elliot R.J., Schuller E., 1986. Feeding frequency for lactating dairy cows: effects on rumen fermentation and blood metabolites and hormones. Brit. J. Nutr. 56, 181-192

Tamminga S., Robinson P.H., Vogt M., Boer H., 1989. Rumen ingesta kinetics of cell wall components in dairy cows. Anim. Feed Sci. Tech. 25, 89-98

Theurer C.B., 1986. Grain processing effects on starch utilization by ruminants. J. Anim. Sci. 63, 1649-! 662 
Thomas E.E., Tumbull G.W. Russell R.W., 1988. Effect of particle size and steam treatment of feedstuffs on rate and extent of digestion (in vitm and in situ). J. Anim. Sci. 66, 243-249

Thomas P.C., Martin P.A., 1988. The influence of nutrient balance on milk yield and composition. In: P.C. Garnsworthy (Editor). Nutrition and Lactation in the Dairy Cow. Butterworths, London, pp. 97-118

Turgeon O.A., Brink D.R., Britton R.A., 1983. Corn particle size mixtures roughage level and starch utilization in finishing steer diets. J. Anim. Sci. 57. 739-749

Van Soest P.J., 1994. Nutritional Ecology of the Ruminant. 2nd Edition. Cornell University Press, Ithaca

Veerkamp R.F., Emmans G.C., 1995. Sources of genetic variation in energetic efficiency of dairy cows. Livest. Prod. Sci. 44, 87-97

Veira D.M., Ivan M., 1983. Rumen ciliate protozoa: Effects on digestion in the stomach of sheep. J. Dairy Sci. 66, 1015-1022

Verbic J.. Stekar J.M.A., Resnik-Cepon M., 1995. Rumen degradation characteristics and fibre composition of various morphological parts of different maize hybrids and possible consequences for breeding. Anim. Feed Sci. Tech. 54, 133-148

Villavicencio E., Rusoff L.L., Girouard R.E., Waters W.H., 1968. Comparison of complete feed rations to a conventional ration for lactating cows. J. Dairy Sci. 51, 1633-1638

Waldo D.R., 1973. Extent and partition of cereal grain starch digestion in ruminants. J. Anim. Sci. 37. $1062-1074$

Whitelaw F.G., Eadie J.M., Bruce L.A.. Shand W.J., 1984. Methane formation in faunated and ciliate-free cattle and its relationship with rumen volatile fatty acid proportions. Brit. J. Nutr. $52,261-275$

Williams A.G., Coleman G.S., 1997. The Rumen protozoa. In: P.N. Hobson, C.S. Stewart (Editors). The Rumen Microbial Ecosystem. 2nd Edition. Blackic Academic and Professional, London, pp. $73-139$

Yan T., Patterson D.C., Grant R.J., 1998. The effect of two methods of feeding the concentrate supplement to dairy cows of high genetic merit. Anim. Sci. 67, 395-403

Yu P., Huber J.T., Santos F.A.P., Simas J., Theurer C.B., 1998. Effects of ground steam-flaked and steam-rolled corn grains on performance of lactating cows. J. Dairy Sci. 81, 777-783

Zinn R.A., 1990. Influence of steaming time on site of digestion of flaked corn in steers. J. Anim. Sci. $68,776-781$

Zinn R.A., Borques J.L., 1993. Influence of sodium bicarbonate and monensin on utilisation of a fat supplemented high energy growing-finishing diet by feedlot steers. J. Anim. Sci. 71, 18-25

Zobel H.F., 1988. Molccules to granules: A comprehensive starch review. Stärke 40, 44-50 


\section{STRESZCZENIE}

\section{Trawienie skrobi u krów mlecznych i propozycja modelu mechanistycznego. 1. Charakterystyka skrobi paszowej $i$ jej trawienie w żwaczu}

Przedstawiono przegląd literatury na temat znaczenia i losów skrobi zawartej w dawkach pokarmowych dla krów mlecznych oraz szczególy dotyczące jej trawienia w żwaczu. Położono nacisk na rolę jaką spełnia populacja drobnoustrojów w procesie rozkładu skrobi i amylolityczną rolę bakterii i pierwotniaków. W opracowaniu wykorzystano danc uzyskane w badaniach in vivo, in vitro i in situ, dotyczących głównie krów mlecznych. Podano równania regresji opisujące zależności wielkości pobrania skrobi, jej źródła i metod obróbki w przebiegu trawienia skrobi. Ilość nic strawionej w żwaczu skrobi przechodzącej do dalszych odcinków przewodu pokarmowego wzrasta wraz z ilością pobrancj z dawką skrobi. Skrobia kukurydzy i sorga jest wolnicj trawiona w żwaczu niż skrobia pochodząca $z$ innych zbóź, co jest korzystne z punktu widzenia jej wykorzystana. Poddanie skrobi obróbce chemicznej i fizycznej, mające na celu zwiększenie trawienia skrobi w żwaczu i całym przewodzie pokarmowym, jest opłacalne. Omówiono inne czynniki wpływające na interpretację danych uzyskanych 7 doświadezeń i brane pod uwage w opracowaniu koncepcyjnego modelu trawienia skrobi. Przedstawiono również wyniki badań nad trawieniem skrobi w żwaczu przy stosowaniu istnicjących już modeli. Podano zasadnicze czynniki opisujące przebieg trawienia skrobi, a które powinny byc uwzględnione w modelu przemian zachodzących w żwaczu. Przedstawiony model opisujący trawienic skrobi u krów mlecznych może być wykorzystany jako część składowa ogólnego modelu opisującego równocześnie przemiany innych składników pokarmowych w żwaczu. 


\begin{tabular}{|c|c|c|c|c|c|c|c|c|c|c|c|c|c|c|c|c|}
\hline Trial & $\begin{array}{l}\text { Milk } \\
\text { Yield }\end{array}$ & $\begin{array}{c}\text { Weight of } \\
\text { animals, kg }\end{array}$ & $\begin{array}{c}\text { No. of } \\
\text { animals }\end{array}$ & Treatment & $\begin{array}{c}\text { Total DMI } \\
\mathrm{kg} / \text { day }\end{array}$ & $\begin{array}{c}\text { Forage intake } \\
\mathrm{kg} / \text { day }\end{array}$ & $\begin{array}{c}\text { Forage as \% DM } \\
\text { intake }\end{array}$ & Forage & Forage source 2 & $\begin{array}{l}\text { Diet } \\
\text { NDF }\end{array}$ & $\begin{array}{l}\text { Diet } \\
\mathrm{CP}\end{array}$ & Starch source & Processing method & $\begin{array}{l}\text { Starch } \\
\text { intake }\end{array}$ & $\begin{array}{l}\text { Starch in } \\
\text { DM\% }\end{array}$ & $\begin{array}{r}\text { Rumen } \\
\mathrm{pH}\end{array}$ \\
\hline 1 & 37.4 & & 32 & Dry rolled barley + cottonseed meal & 25.3 & 8.9 & $35 \%$ & Lucerne hay & Cottonseed hulls & $34 \%$ & $17 \%$ & Barley & Dry rolled & 8298 & $33 \%$ & \\
\hline 1 & 34.9 & & 32 & Dry rolled barley + brewers dried grains & 23.7 & 8.3 & $35 \%$ & Lucerne hay & Cottonseed hulls & $37 \%$ & $18 \%$ & Barley & Dry rolled & 7134 & $30 \%$ & \\
\hline 1 & 34.2 & & 32 & Dry rolled sorghum + cottonseed meal & 24.3 & 8.5 & $35 \%$ & Lucerne hay & Cottonseed hulls & $33 \%$ & $17 \%$ & Sorghum & Dry rolled & 7314 & $30 \%$ & \\
\hline 1 & 34.6 & & 32 & Dry rolled sorghum + brewers dried grains & 23.8 & 8.3 & $35 \%$ & Lucerne hay & Cottonseed hulls & $35 \%$ & $18 \%$ & Sorghum & Dry rolled & 5807 & $24 \%$ & \\
\hline 2 & 32.4 & 583 & 4 & Steam rolled barley + fishmeal & 20.5 & 9.2 & $45 \%$ & Lucerne haylage & Maize silage & $36 \%$ & $15 \%$ & Barley & Steam rolled & 8200 & $40 \%$ & 5.62 \\
\hline 2 & 32.6 & 583 & 4 & Steam rolled barley + soyabean meal & 20.9 & 9.4 & $45 \%$ & Lucerne haylage & Maize silage & $33 \%$ & $15 \%$ & Barley & Steam rolled & 8600 & $41 \%$ & 5.73 \\
\hline 2 & 35.9 & 583 & 4 & Ground shelled maize + fishmeal & 23.3 & 10.5 & $45 \%$ & Lucerne haylage & Maize silage & $34 \%$ & $15 \%$ & Maize & Dry ground & 10300 & $44 \%$ & 5.96 \\
\hline 2 & 35.2 & 583 & 4 & Ground shelled maize + soyabean meal & 24.2 & 10.9 & $45 \%$ & Lucerne haylage & Maize silage & $30 \%$ & $15 \%$ & Maize & Dry ground & 11000 & $45 \%$ & 5.72 \\
\hline 3 & & & 4 & Dry rolled sorghum + brewers dried grains & 18.3 & 6.4 & $35 \%$ & Lucerne hay & Cottonseed hulls & $45 \%$ & $18 \%$ & Sorghum & Dry rolled & 4470 & $24 \%$ & 6 \\
\hline 3 & & & 4 & Dry rolled barley + cottonseed meal & 18.3 & 6.4 & $35 \%$ & Lucerne hay & Cottonseed hulls & $41 \%$ & $17 \%$ & Barley & Dry rolled & 5810 & $32 \%$ & 5.6 \\
\hline 3 & & & 4 & Dry rolled barley + brewers dried grains & 19.6 & 6.8 & $35 \%$ & Lucerne hay & Cottonseed hulls & $45 \%$ & $18 \%$ & Barley & Dry rolled & 5960 & $30 \%$ & 5.7 \\
\hline 3 & & & 4 & Dry rolled sorghum + cottonseed meal & 20.3 & 7.1 & $35 \%$ & Lucerne hay & Cottonseed hulls & $39 \%$ & $17 \%$ & Sorghum & Dry rolled & 6300 & $31 \%$ & 5.9 \\
\hline 4 & 29.3 & 580 & 4 & $14.5 \%$ CP soybean meal & 21.8 & 13.1 & $60 \%$ & Maize silage & & $39 \%$ & $15 \%$ & Maize & Dry ground & 9047 & $42 \%$ & 5.89 \\
\hline 4 & 29.6 & 580 & 4 & $14.5 \% \mathrm{CP}$ maize gluten meal & 20.9 & 12,5 & $60 \%$ & Maize silage & & $37 \%$ & $15 \%$ & Maize & Dry ground & 9447 & $45 \%$ & 5.84 \\
\hline 4 & 26.9 & 580 & 4 & $11 \%$ CP soyabean meal & 20.9 & 12,5 & $60 \%$ & Maize silage & & $37 \%$ & $11 \%$ & Maize & Dry ground & 9739 & $47 \%$ & 6.14 \\
\hline 4 & 26.6 & 580 & 4 & $11 \% \mathrm{CP}$ maize gluten meal & 21.6 & 13.0 & $60 \%$ & Maize silage & & $37 \%$ & $11 \%$ & Maize & Dry ground & 10282 & $48 \%$ & 6.14 \\
\hline 5 & 31.8 & & 4 & Urea $0.75 \% \mathrm{DM}$ & 23.0 & 12.7 & $55 \%$ & Lucerne haylage & Maize silage & $33 \%$ & $17 \%$ & Maize & Dry ground & 7500 & $33 \%$ & 5.96 \\
\hline 5 & 31.2 & & 4 & Control & 23.1 & 12.7 & $55 \%$ & Lucerne haylage & Maize silage & $33 \%$ & $15 \%$ & Maize & Dry ground & 7600 & $33 \%$ & 5.94 \\
\hline 5 & 31.4 & & 4 & Starch + urea $0.75 \% \mathrm{DM}$ & 21.0 & 8.9 & $43 \%$ & Lucerne haylage & Maize silage & $27 \%$ & $17 \%$ & Maize & Dry ground & 8000 & $38 \%$ & 5.74 \\
\hline 5 & 29.9 & & 4 & Starch & 21.6 & 9.2 & $43 \%$ & Lucerne haylage & Maize silage & $28 \%$ & $15 \%$ & Maize & Dry ground & 8300 & $38 \%$ & 5.9 \\
\hline 6 & 35.7 & & 4 & High forage + Ca LCFA & 23.3 & 15.6 & $67 \%$ & Lucerne haylage & Maize silage & $34 \%$ & $18 \%$ & Maize & Dry ground & 5900 & $26 \%$ & 5.92 \\
\hline 6 & 37.4 & & 4 & Low forage + Ca LCFA & 24.0 & 12.0 & $50 \%$ & Lucerne haylage & Maize silage & $30 \%$ & $18 \%$ & Maize & Dry ground & 8000 & $34 \%$ & 5.69 \\
\hline 6 & 40.5 & & 4 & Fish meal + Ca LCFA & 22.3 & 11.2 & $50 \%$ & Lucerne haylage & Maize silage & $33 \%$ & $18 \%$ & Maize & Dry ground & 8900 & $40 \%$ & 5.9 \\
\hline 6 & 39.9 & & 4 & Soyabean meal + Ca LCFA & 23.8 & 11.9 & $50 \%$ & Lucerne haylage & Maize silage & $33 \%$ & $18 \%$ & Maize & Dry ground & 9000 & $38 \%$ & 5.5 \\
\hline 7 & 35.3 & & 4 & High forage & 24.7 & 16.5 & $67 \%$ & Lucerne haylage & Maize silage & $35 \%$ & $18 \%$ & Maize & Dry ground & 7000 & $28 \%$ & 5.81 \\
\hline 7 & 36 & & 4 & Low forage & 22.5 & 11.3 & $50 \%$ & Lucerne haylage & Maize silage & $30 \%$ & $18 \%$ & Maize & Dry ground & 9300 & $36 \%$ & 5.53 \\
\hline 7 & 41.7 & & 4 & Fish meal & 23.4 & 11.7 & $50 \%$ & Lucerne haylage & Maize silage & $34 \%$ & $18 \%$ & Maize & Dry ground & 9800 & $42 \%$ & 5.7 \\
\hline 7 & 39.9 & & 4 & Soyabean meal & 25.1 & 12.6 & $50 \%$ & Lucerne haylage & Maize silage & $33 \%$ & $18 \%$ & Maize & Dry ground & 10600 & $42 \%$ & 5.7 \\
\hline 8 & 27.9 & 553 & 4 & Control $+24 \mathrm{~g}$ lysine $+8 \mathrm{~g}$ methionine & 19.4 & 13.0 & $67 \%$ & Maize silage & Grass hay & $35 \%$ & $15 \%$ & Maize & Dry ground & 5500 & $28 \%$ & 6.05 \\
\hline 8 & 29.1 & 553 & 4 & Control & 19.9 & 13.4 & $67 \%$ & Maize silage & Grass hay & $35 \%$ & $15 \%$ & Maize & Dry ground & 5800 & $29 \%$ & 6.03 \\
\hline 8 & 33.3 & 553 & 4 & Control $+25 \mathrm{mg}$ bST & 20.0 & 13.4 & $67 \%$ & Maize silage & Grass hay & $35 \%$ & $15 \%$ & Maize & Dry ground & 5800 & $29 \%$ & 6.07 \\
\hline 8 & 31.2 & 553 & 4 & Control $+25 \mathrm{mg} \mathrm{bST}+24 \mathrm{~g} \mathrm{Lys}+8 \mathrm{~g} \mathrm{Met}$ & 19.9 & 13.4 & $67 \%$ & Maize silage & Grass hay & $35 \%$ & $15 \%$ & Maize & Dry ground & 5800 & $29 \%$ & 6.01 \\
\hline 9 & 16 & 630 & 2 & $5 \%$ added fat $+8 \%$ added animal protein & 16.0 & 6.0 & $38 \%$ & Grass silage & & $28 \%$ & $30 \%$ & Barley & & 1590 & $10 \%$ & \\
\hline 9 & 16.2 & 630 & 2 & $5 \%$ added fat & 16.2 & 6.2 & $38 \%$ & Grass silage & & $28 \%$ & $23 \%$ & Barley + Peas & & 2420 & $15 \%$ & \\
\hline 9 & 17.2 & 630 & 2 & $8 \%$ added animal protein & 17.3 & 7.3 & $42 \%$ & Grass silage & & $29 \%$ & $27 \%$ & Barley & & 2910 & $17 \%$ & \\
\hline 9 & 17.9 & 630 & 2 & Control & 17.1 & 7.1 & $41 \%$ & Grass silage & & $29 \%$ & $20 \%$ & Barley + Peas & & 4160 & $24 \%$ & \\
\hline 10 & 19.2 & & 4 & Lucerne hay + steam flaked sorghum & 20.7 & 10.8 & $52 \%$ & Lucerne hay & & $26 \%$ & $16 \%$ & Sorghum & Steam flaked & 6130 & $29 \%$ & \\
\hline 10 & 18.2 & & 4 & Lucerne hay + dry rolled sorghum & 20.7 & 10.8 & $52 \%$ & Lucerne hay & & $25 \%$ & $17 \%$ & Sorghum & Dry rolled & 6190 & $30 \%$ & \\
\hline 10 & 19.6 & & 4 & Wheat straw + steam flaked sorghum & 20.7 & 7.4 & $36 \%$ & Wheat straw & Lucerne hay & $27 \%$ & $17 \%$ & Sorghum & Steam flaked & 6760 & $32 \%$ & \\
\hline 10 & 18.6 & & 4 & Wheat straw + dry rolled sorghum & 21.3 & 7.6 & $36 \%$ & Wheat straw & Lucerne hay & $26 \%$ & $17 \%$ & Sorghum & Dry rolled & 7180 & $33 \%$ & \\
\hline 11 & 28.6 & & 22 & Lucerne hay + dry rolled sorghum & 21.1 & 11.0 & $52 \%$ & Lucerne hay & & $29 \%$ & $16 \%$ & Sorghum & Dry rolled & 5275 & $25 \%$ & \\
\hline 11 & 31.3 & & 22 & Lucerne hay + steam flaked sorghum & 20.6 & 10.8 & $52 \%$ & Lucerne hay & & $30 \%$ & $17 \%$ & Sorghum & Steam flaked & 5150 & $25 \%$ & \\
\hline 11 & 27.6 & & 22 & Wheat straw + dry rolled sorghum & 20.2 & 6.2 & $31 \%$ & Wheat straw & & $30 \%$ & $17 \%$ & Sorghum & Dry rolled & 5050 & $29 \%$ & \\
\hline 11 & 31.6 & & 22 & Wheat straw + steam flaked sorghum & 20.0 & 6.1 & $31 \%$ & Wheat straw & & $31 \%$ & $16 \%$ & Sorghum & Steam flaked & 5000 & $29 \%$ & \\
\hline 12 & 34.6 & & 24 & Steam flaked maize & 25.2 & 8.6 & $34 \%$ & Lucerne hay & & $30 \%$ & $19 \%$ & Maize & Steam flaked & 7560 & $30 \%$ & \\
\hline 12 & 32.1 & & 24 & Steam rolled maize & 23.5 & 8.0 & $34 \%$ & Lucerne hay & & $31 \%$ & $21 \%$ & Maize & Steam rolled & 6956 & $30 \%$ & \\
\hline 12 & 35 & & 24 & Steam flaked sorghum & 25.5 & 8.7 & $34 \%$ & Lucerne hay & & $31 \%$ & $20 \%$ & Sorghum & Steam flaked & 7854 & $31 \%$ & \\
\hline 12 & 31.1 & & 24 & Steam rolled sorghum & 24.5 & 8.3 & $34 \%$ & Lucerne hay & & $29 \%$ & $22 \%$ & Sorghum & Steam rolled & 7448 & $30 \%$ & \\
\hline 13 & 25.2 & 538 & 5 & Ground maize $25 \%$, steam rolled barley $75 \%$ & 19.5 & 8.8 & $45 \%$ & Lucerne silage & Maize silage & $35 \%$ & $16 \%$ & Maize - barley & Ground steam rolled & 6600 & $34 \%$ & 5.82 \\
\hline 13 & 22.6 & 538 & 5 & Steam rolled barley & 19.6 & 8.8 & $45 \%$ & Lucerne silage & Maize silage & $37 \%$ & $16 \%$ & Barley & Steam rolled & 6700 & $34 \%$ & 5.79 \\
\hline 13 & 26.6 & 538 & 5 & Ground maize $50 \%$, steam rolled barley $50 \%$ & \% 21.3 & 9.6 & $45 \%$ & Lucerne silage & Maize silage & $34 \%$ & $16 \%$ & Maize - barley & Ground steam rolled & 7100 & $33 \%$ & 5.85 \\
\hline 13 & 27.8 & 538 & 5 & Ground maize $75 \%$, steam rolled barley $25 \%$ & 622.1 & 9.9 & $45 \%$ & Lucerne silage & Maize silage & $34 \%$ & $16 \%$ & Maize - barley & Ground steam rolled & 7300 & $33 \%$ & 5.82 \\
\hline 13 & 26.9 & 538 & 5 & Ground maize & 22.8 & 10.3 & $45 \%$ & Lucerne silage & Maize silage & $34 \%$ & $16 \%$ & Maize & Dry ground & 7500 & $33 \%$ & 5.91 \\
\hline 14 & 22.9 & & 4 & Dry rolled maize & 16.5 & 7.2 & $43 \%$ & Lucerne hay & & & & Maize & Dry rolled & 3906 & $24 \%$ & 6.32 \\
\hline 14 & 25.6 & & 4 & Steam flaked maize $0.32 \mathrm{~kg} / 1$ & 17.3 & 7.5 & $43 \%$ & Lucerne hay & & & & Maize & Steam flaked & 4280 & $25 \%$ & 6.37 \\
\hline
\end{tabular}




\begin{tabular}{|c|c|c|c|c|c|c|c|c|c|c|c|c|c|c|c|c|}
\hline Trial & Acatate & Propionate & Butryrate & $\mathrm{A}+\mathrm{B} / \mathrm{P}$ & $\begin{array}{c}\text { Total VFA } \\
\text { mM }\end{array}$ & $\begin{array}{l}\text { Digested in } \\
\text { rumen, } \mathrm{g}\end{array}$ & $\begin{array}{l}\text { \% Digestibility } \\
\text { in rumen }\end{array}$ & $\begin{array}{l}\text { Rumen digestion as } \\
\text { a \% of total }\end{array}$ & $\begin{array}{c}\text { Entering } \\
\text { SI }\end{array}$ & $\begin{array}{l}\text { Faecal starch } \\
\text { g/day }\end{array}$ & $\begin{array}{c}\text { Postruminal } \\
\text { digestion, g/day }\end{array}$ & $\begin{array}{c}\text { Postruminal } \\
\text { digestion \% intake }\end{array}$ & $\begin{array}{c}\text { Postruminal digestibility } \\
\% \text { entering SI }\end{array}$ & $\begin{array}{l}\text { Postruminal as a \% of } \\
\text { total digestion }\end{array}$ & $\begin{array}{l}\text { Digested in total } \\
\text { tract, g/day }\end{array}$ & $\begin{array}{r}\text { Total tract } \\
\text { digestibility, \% }\end{array}$ \\
\hline 1 & 56.5 & 28.6 & 9.4 & 2.30 & 26 & & & & & 647 & & & & & 7651 & 92.2 \\
\hline 1 & 54.7 & 29.9 & 9.5 & 2.15 & 20 & & & & & 870 & & & & & 6263 & 87.8 \\
\hline 1 & 56.7 & 27.7 & 10 & 2.41 & 23 & & & & & 1426 & & & & & 5888 & 80.5 \\
\hline 1 & 57.5 & 26 & 10.5 & 2.62 & 18 & & & & & 1132 & & & & & 4675 & 80.5 \\
\hline 2 & 56.37 & 32.98 & 8.24 & 1.96 & 123 & 6300 & $77 \%$ & $79 \%$ & 1900 & 271 & 1629 & $20 \%$ & $86 \%$ & $21 \%$ & 7929 & 96.7 \\
\hline 2 & 58.29 & 28.97 & 10.17 & 2.36 & 119 & 6700 & $78 \%$ & $80 \%$ & 1900 & 275 & 1625 & $19 \%$ & $86 \%$ & $20 \%$ & 8325 & 96.8 \\
\hline 2 & 61.61 & 23.95 & 11.54 & 3.05 & 104 & 5300 & $51 \%$ & $55 \%$ & 5000 & 731 & 4269 & $41 \%$ & $85 \%$ & $45 \%$ & 9569 & 92.9 \\
\hline 2 & 58.42 & 28.75 & 10.2 & 2.39 & 119 & 5100 & $46 \%$ & $50 \%$ & 5800 & 715 & 5085 & $46 \%$ & $88 \%$ & $49 \%$ & 10285 & 93.5 \\
\hline 3 & 62.8 & 19.8 & 13.3 & 3.84 & 39 & 1971 & $44 \%$ & $51 \%$ & 2499 & 636 & 1863 & $42 \%$ & $75 \%$ & $49 \%$ & 3834 & 85.8 \\
\hline 3 & 56.3 & 28.8 & 11.2 & 2.34 & 42 & 4642 & $80 \%$ & $85 \%$ & 1168 & 335 & 833 & $14 \%$ & $71 \%$ & $15 \%$ & 5475 & 94.2 \\
\hline 3 & 55.1 & 28.7 & 12 & 2.34 & 40 & 4768 & $80 \%$ & $85 \%$ & 1192 & 376 & 816 & $14 \%$ & $68 \%$ & $15 \%$ & 5584 & 93.7 \\
\hline 3 & 63.7 & 20.6 & 11.6 & 3.66 & 42 & 3137 & $50 \%$ & $55 \%$ & 3163 & 645 & 2518 & $40 \%$ & $80 \%$ & $45 \%$ & 5655 & 89.8 \\
\hline 4 & 57.2 & 25.6 & 13.4 & 2.76 & 113 & 5274 & $58 \%$ & $61 \%$ & 3773 & 443 & 3329 & $37 \%$ & $88 \%$ & $39 \%$ & 8604 & 95.1 \\
\hline 4 & 58.7 & 25.3 & 12.4 & 2.81 & 105 & 5007 & $53 \%$ & $56 \%$ & 4440 & 576 & 3864 & $41 \%$ & $87 \%$ & $44 \%$ & 8871 & 93.9 \\
\hline 4 & 61.4 & 21.4 & 12.8 & 3.47 & 99 & 5162 & $53 \%$ & $57 \%$ & 4578 & 701 & 3876 & $40 \%$ & $85 \%$ & $43 \%$ & 9038 & 92.8 \\
\hline 4 & 59.7 & 22.3 & 14 & 3.30 & 90 & 5717 & $56 \%$ & $61 \%$ & 4565 & 864 & 3701 & $36 \%$ & $81 \%$ & $39 \%$ & 9418 & 91.6 \\
\hline 5 & 64 & 21.2 & 12.2 & 3.59 & 114 & 2580 & $34 \%$ & $36 \%$ & 4900 & 248 & 4653 & $62 \%$ & $95 \%$ & $64 \%$ & 7253 & 96.7 \\
\hline 5 & 65.2 & 20.6 & 11.4 & 3.72 & 113 & 3458 & $46 \%$ & $47 \%$ & 4200 & 228 & 3972 & $52 \%$ & $94 \%$ & $54 \%$ & 7372 & 97.0 \\
\hline 5 & 59.8 & 27 & 10.9 & 2.62 & 121 & 4192 & $52 \%$ & $53 \%$ & 3800 & 120 & 3680 & $46 \%$ & $95 \%$ & $47 \%$ & 7880 & 98.5 \\
\hline 5 & 63.1 & 20.9 & 13.2 & 3.65 & 109 & 4075 & $49 \%$ & $51 \%$ & 4200 & 291 & 3910 & $47 \%$ & $93 \%$ & $49 \%$ & 8010 & 96.5 \\
\hline 6 & 63.4 & 21.9 & 11.1 & 3.40 & 133 & 3098 & $53 \%$ & $54 \%$ & 2800 & 207 & 2594 & $44 \%$ & $91 \%$ & $46 \%$ & 5694 & 96.5 \\
\hline 6 & 58.7 & 27.3 & 10.6 & 2,54 & 143 & 3472 & $43 \%$ & $45 \%$ & 4400 & 328 & 4072 & $53 \%$ & $92 \%$ & $53 \%$ & 7672 & 95.9 \\
\hline 6 & 60.8 & 25.6 & 10.1 & 2,77 & 123 & 3711 & $42 \%$ & $44 \%$ & 5200 & 374 & 4826 & $54 \%$ & $93 \%$ & $57 \%$ & 8526 & 95.8 \\
\hline 6 & 59.7 & 26.5 & 10.3 & 2,64 & 133 & 3591 & $40 \%$ & $42 \%$ & 5400 & 378 & 5022 & $56 \%$ & $93 \%$ & $58 \%$ & 8622 & 95.8 \\
\hline 7 & 62.7 & 23 & 11.1 & 3,21 & 134 & 3458 & $49 \%$ & $51 \%$ & 3500 & 259 & 3241 & $47 \%$ & $91 \%$ & $48 \%$ & 6741 & 96.3 \\
\hline 7 & 57.5 & 29.2 & 10 & 2,31 & 145 & 4641 & $50 \%$ & $52 \%$ & 4700 & 372 & 4328 & $46 \%$ & $92 \%$ & $48 \%$ & 8928 & 96.0 \\
\hline 7 & 60.6 & 26.1 & 10 & 2,70 & 126 & 4508 & $46 \%$ & $49 \%$ & 5300 & 578 & 4722 & $48 \%$ & $88 \%$ & $51 \%$ & 9222 & 94.1 \\
\hline 7 & 59.3 & 27.5 & 9.9 & 2,52 & 128 & 5141 & $49 \%$ & $52 \%$ & 5400 & 731 & 4669 & $45 \%$ & $85 \%$ & $47 \%$ & 9869 & 93.1 \\
\hline 8 & 63.1 & 22.3 & 12 & 3,37 & 106 & 2376 & $43 \%$ & $45 \%$ & 3300 & 200 & 3100 & $53 \%$ & $93 \%$ & $58 \%$ & 5300 & 96.2 \\
\hline 8 & 63.5 & 21.9 & 11.9 & 3,44 & 107 & 2511 & $43 \%$ & $46 \%$ & 3600 & 300 & 3300 & $52 \%$ & $90 \%$ & $60 \%$ & 5500 & 94.8 \\
\hline 8 & 63.7 & 21.1 & 12.6 & 3,62 & 106 & 1775 & $31 \%$ & $32 \%$ & 4100 & 200 & 3900 & $65 \%$ & $93 \%$ & $70 \%$ & 5600 & 94.8 \\
\hline 8 & 62.6 & 21.8 & 12.9 & 3,46 & 108 & 2326 & $40 \%$ & $42 \%$ & 3600 & 200 & 3400 & $57 \%$ & $94 \%$ & $61 \%$ & 5600 & 96.4 \\
\hline 9 & 61.8 & 20.4 & 12 & 3,62 & 142 & 1417 & $89 \%$ & $90 \%$ & 173 & 13 & 160 & $10 \%$ & $92 \%$ & $10 \%$ & 1577 & 99.2 \\
\hline 9 & 60.1 & 21 & 12.8 & 3,47 & 140 & 2179 & $90 \%$ & $91 \%$ & 241 & 15 & 226 & $9 \%$ & $94 \%$ & $9 \%$ & 2405 & 99.4 \\
\hline 9 & 61.2 & 19.9 & 12.9 & 3,72 & 150 & 2683 & $92 \%$ & $93 \%$ & 227 & 20 & 207 & $7 \%$ & $91 \%$ & $7 \%$ & 2890 & 99.3 \\
\hline 9 & 59.2 & 22.2 & 12.8 & 3,24 & 136 & 3693 & $89 \%$ & $89 \%$ & 467 & 30 & 437 & $11 \%$ & $94 \%$ & $11 \%$ & 4130 & 99.3 \\
\hline 10 & & & & & & 4300 & $70 \%$ & $72 \%$ & 1830 & 140 & 1690 & $28 \%$ & $92 \%$ & $28 \%$ & 5990 & 97.8 \\
\hline 10 & & & & & & 2620 & $42 \%$ & $50 \%$ & 3570 & 960 & 2610 & $42 \%$ & $73 \%$ & $50 \%$ & 5230 & 84.6 \\
\hline 10 & & & & & & 5160 & $76 \%$ & $78 \%$ & 1600 & 130 & 1470 & $22 \%$ & $92 \%$ & $22 \%$ & 6630 & 98.0 \\
\hline 10 & & & & & & 3900 & $54 \%$ & $68 \%$ & 3280 & 1440 & 1840 & $26 \%$ & $56 \%$ & $32 \%$ & 5740 & 80.9 \\
\hline 11 & 68.5 & 17.5 & 11 & 4.54 & 77 & & & & & 1087 & & & & & 4188 & 79.4 \\
\hline 11 & 64.9 & 20.7 & 11.4 & 3.69 & 68 & & & & & 160 & & & & & 4990 & 96.9 \\
\hline 11 & 68 & 20 & 9.3 & 3.87 & 57 & & & & & 939 & & & & & 4111 & 81.4 \\
\hline 11 & 62.9 & 25 & 9.6 & 2.90 & 62 & & & & & 170 & & & & & 4830 & 96.6 \\
\hline 12 & & & & & & & & & & 310 & & & & & 7250 & 95.9 \\
\hline 12 & & & & & & & & & & 570 & & & & & 6386 & 91.8 \\
\hline 12 & & & & & & & & & & 181 & & & & & 7673 & 97.7 \\
\hline 12 & & & & & & & & & & 648 & & & & & 6800 & 91.3 \\
\hline 13 & 56.1 & 32.2 & 9 & 2.2 & 119 & 4900 & $74 \%$ & $78 \%$ & 1700 & 300 & 1400 & $21 \%$ & $80 \%$ & $22 \%$ & 6300 & 95.4 \\
\hline 13 & 56.1 & 31.7 & 9.4 & 2.07 & 123 & 5000 & $74 \%$ & $78 \%$ & 1700 & 300 & 1400 & $22 \%$ & $81 \%$ & $22 \%$ & 6400 & 96.2 \\
\hline 13 & 57.1 & 30.5 & 9.8 & 2.19 & 121 & 4300 & $61 \%$ & $65 \%$ & 2700 & 500 & 2300 & $33 \%$ & $80 \%$ & $35 \%$ & 6600 & 93.8 \\
\hline 13 & 58 & 29.6 & 9.8 & 2.29 & 122 & 4500 & $61 \%$ & $66 \%$ & 2800 & 500 & 2300 & $33 \%$ & $80 \%$ & $34 \%$ & 6800 & 93.5 \\
\hline 13 & 61.1 & 24.9 & 11.2 & 2.90 & 120 & 3200 & $42 \%$ & $47 \%$ & 4300 & 700 & 3600 & $49 \%$ & $81 \%$ & $53 \%$ & 6800 & 90.8 \\
\hline 14 & 68.4 & 19.1 & 12.3 & 4.23 & & 1863 & $48 \%$ & $62 \%$ & 2043 & 906 & 1137 & $29 \%$ & $56 \%$ & $38 \%$ & 3000 & 76.8 \\
\hline 14 & 63.6 & 24.4 & 11.8 & 3.09 & & 2765 & $65 \%$ & $67 \%$ & 1515 & 138 & 1377 & $32 \%$ & $91 \%$ & $33 \%$ & 4142 & 96.8 \\
\hline
\end{tabular}




\begin{tabular}{|c|c|c|c|c|c|c|c|c|c|c|c|c|c|c|c|}
\hline Acatate & Propionate & Butryrate & $\mathrm{A}+\mathrm{B} / \mathrm{P}$ & $\begin{array}{c}\text { Total VFA } \\
\mathrm{mM}\end{array}$ & $\begin{array}{l}\text { Digested in } \\
\text { rumen, } g\end{array}$ & $\begin{array}{l}\text { \% Digestibility } \\
\text { in rumen }\end{array}$ & $\begin{array}{c}\text { Rumen digestion as } \\
\text { a \% of total }\end{array}$ & $\begin{array}{c}\text { Entering } \\
\text { SI }\end{array}$ & $\begin{array}{l}\text { Faecal starch } \\
\text { g/day }\end{array}$ & $\begin{array}{c}\text { Postruminal } \\
\text { digestion, g/day }\end{array}$ & $\begin{array}{c}\text { Postruminal } \\
\text { digestion \% intake }\end{array}$ & $\begin{array}{l}\text { Postruminal digestibility } \\
\% \text { entering SI }\end{array}$ & $\begin{array}{l}\text { Postruminal as a \% of } \\
\text { total digestion }\end{array}$ & $\begin{array}{l}\text { Digested in total } \\
\text { tract, g/day }\end{array}$ & $\begin{array}{r}\text { Total tract } \\
\text { digestibility, \% }\end{array}$ \\
\hline 66.3 & 20.4 & 13.1 & 3.89 & & 2025 & $47 \%$ & $50 \%$ & 2312 & 317 & 1995 & $46 \%$ & $86 \%$ & $50 \%$ & 4020 & 92.7 \\
\hline 62.3 & 26.4 & 11.2 & 2.78 & & 3271 & $69 \%$ & $69 \%$ & 1497 & 17 & 1480 & $31 \%$ & $99 \%$ & $31 \%$ & 4751 & 99.6 \\
\hline 64.92 & 2089 & 11.07 & 3.64 & 121 & 2500 & $72 \%$ & $72 \%$ & 1000 & 25 & 976 & $27 \%$ & $97 \%$ & $28 \%$ & 3476 & 99.3 \\
\hline 64.84 & 20.75 & 11.35 & 3.67 & 115 & 2400 & $69 \%$ & $69 \%$ & 1100 & 25 & 1076 & $30 \%$ & $98 \%$ & $31 \%$ & 3476 & 99.3 \\
\hline 64.34 & 20.75 & 11.67 & 3.66 & 113 & 2400 & $66 \%$ & $65 \%$ & 1300 & 26 & 1274 & $33 \%$ & $98 \%$ & $35 \%$ & 3674 & 99.3 \\
\hline 66.29 & 18.46 & 12.36 & 4.26 & 104 & 1060 & $34 \%$ & $47 \%$ & 1830 & 650 & 1190 & $44 \%$ & $64 \%$ & $53 \%$ & 2250 & 78.0 \\
\hline 65.25 & 19.13 & 12.72 & 4.08 & 102 & 760 & $27 \%$ & $32 \%$ & 2070 & 530 & 1640 & $58 \%$ & $80 \%$ & $68 \%$ & 2400 & 85.1 \\
\hline 64.33 & 20.38 & 12.4 & 3.76 & 112 & 1430 & $45 \%$ & $60 \%$ & 1770 & 800 & 1590 & $50 \%$ & $90 \%$ & $66 \%$ & 2400 & 94.4 \\
\hline
\end{tabular}


